\title{
Life Cycle Models and Forecasting Growth and Profitability
}

Citation for published version (APA):

Vorst, P., \& Lombardi Yohn, T. (2018). Life Cycle Models and Forecasting Growth and Profitability. Accounting Review, 93(6), 357-381. https://doi.org/10.2308/accr-52091

Document status and date:

Published: 01/11/2018

DOI:

10.2308/accr-52091

Document Version:

Publisher's PDF, also known as Version of record

Document license:

Taverne

Please check the document version of this publication:

- A submitted manuscript is the version of the article upon submission and before peer-review. There can be important differences between the submitted version and the official published version of record.

People interested in the research are advised to contact the author for the final version of the publication, or visit the DOI to the publisher's website.

- The final author version and the galley proof are versions of the publication after peer review.

- The final published version features the final layout of the paper including the volume, issue and page numbers.

Link to publication

\footnotetext{
General rights rights.

- You may freely distribute the URL identifying the publication in the public portal. please follow below link for the End User Agreement:

www.umlib.nl/taverne-license

Take down policy

If you believe that this document breaches copyright please contact us at:

repository@maastrichtuniversity.nl

providing details and we will investigate your claim.
}

Copyright and moral rights for the publications made accessible in the public portal are retained by the authors and/or other copyright owners and it is a condition of accessing publications that users recognise and abide by the legal requirements associated with these

- Users may download and print one copy of any publication from the public portal for the purpose of private study or research.

- You may not further distribute the material or use it for any profit-making activity or commercial gain

If the publication is distributed under the terms of Article $25 \mathrm{fa}$ of the Dutch Copyright Act, indicated by the "Taverne" license above, 


\title{
Life Cycle Models and Forecasting Growth and Profitability
}

\author{
Patrick Vorst \\ Maastricht University \\ School of Business and Economics \\ $\&$ \\ Indiana University \\ Kelley School of Business \\ p.vorst@maastrichtuniversity.nl \\ pvorst@indiana.edu
}

\author{
Teri Lombardi Yohn \\ Indiana University \\ Kelley School of Business \\ tyohn@indiana.edu
}

May, 2017

\begin{abstract}
Mean reversion in profitability and growth is a well-documented phenomenon in prior literature. However, we know comparatively less about the underlying process that drives such mean reversion. Whereas prior literature has shown that assuming industry-level mean reversion improves forecast accuracy of models predicting firm growth, forecasts of firm profitability are better modeled using economy-wide parameters. In this study, we extend this literature by investigating the relative forecast accuracy of mean reverting models based on firm life cycle. Life cycle reflects a firm's evolvement arising from changes in both internal and external factors and is recognized to have a substantial impact on firm-decision making and firm profitability. Hence, assuming that firms' profitability and growth parameters revert to the mean for their respective life cycle may lead to more accurate out-of-sample forecasts. Consistent with this expectation we find that life cycle models improve forecast accuracy of both growth and profitability forecasts, outperforming economy-wide and industry-specific models in forecasting a wide range of profitability and growth measures in the short-term and the long-term.
\end{abstract}




\section{INTRODUCTION}

In this study, we investigate the accuracy of a forecast model based on firm life cycle for predicting future profitability and growth relative to economy-wide and industry-specific forecast models. Whereas, mean reversion in profitability and growth is a well-documented phenomenon (Fairfield, Sweeney, and Yohn 1996; Nissim and Penman 2001), comparatively less is known about the drivers of such mean reversion. Many studies in the accounting and finance literatures focus on industry as an important driver of cross-sectional variation in firm profitability and growth dynamics. There is substantial evidence that supports the importance of industry as a determinant of firm fundamentals. Foster (1981) finds evidence of intra-industry information transfers around earnings announcements. Hui, Nelson, and Yeung (2016) find that the industry-wide component of earnings exhibits greater persistence than the firm-specific component of earnings. Outside of accounting, studies in the organization literature provide support for the importance of industry in the determination of a firm's long-run profitability (Hawawini, Subramanian, and Verdin 2003; Bou and Satorra 2007). Notwithstanding these findings, from a forecasting perspective, Fairfield, Ramnath, and Yohn (2009) show that while industry-level analyses are incrementally informative for forecasting growth, forecasts of profitability are not improved by industry-level analyses. Although forecasting growth is important, ultimately growth does not add value unless firms are able to exploit it profitably. Hence, profitability forecasts remain a key input in the investment decision-making process, illustrating the importance of finding methods that can be used to improve their quality.

In this study, we extend this literature and investigate the performance of a life cycle model for the prediction of growth and profitability relative to an economy-wide model and an industryspecific model. A number of studies in the organization literature have posited that a firm's 
structure, decisions, and development are predictable and can be modeled as a function of organizational life cycle (Adizes 1979; Kimberly 1979; Miller and Friesen 1983, 1984). With each life cycle stage being significantly different from the other stages across a variety of dimensions, firms' movement through the different stages of development will bring about predictable changes in key organizational factors. As a result, a number of studies have used life cycle theory to explain a variety of firm characteristics including a firm's dividend policy (DeAngelo, DeAngelo, and Stulz 2006; Grullon, Michaely, and Swaminathan 2002), takeover activity (Owen and Yawson 2010), diversification (Arikan and Stulz 2016), board composition (Lynall, Golden, and Hillman 2003), and management accounting systems (Moores and Yuen 2001).

The substantial differences that exist between firms in different life cycle stages suggest that organizational life cycle is a potentially good conditioning variable for the estimation of mean-reverting models. Estimating economy-wide mean reverting models assumes that all firms in the economy exhibit the same degree of mean reversion. However, to the extent that there are substantial differences across firms, such models can be improved by classifying firms into groups of similar firms. These finer classifications likely work best if there is substantial heterogeneity across groups, while maintaining within-group homogeneity. Supporting the relevance of life cycle in such a setting, Miller and Friesen (1984) state that "periods of the life cycle differ from one another in very pervasive and multifaceted ways. Each of the phases is in many ways unique." These differences also extend to an accounting setting. For example, Anthony and Ramesh (1992) show that life cycle affects the value-relevance of various accounting measures, while Hribar and Yehuda (2015) find that life cycle affects the behavior 
and role of accruals. Moreover, Dickinson (2011) finds considerable differences in average profitability across life cycle stages that persist for up to five years after the initial classification.

Importantly, while there are substantial differences across the life cycle stages, there is evidence that suggests that firms within a life cycle stage have similar characteristics. For example, while Porter (1979) finds considerable within-industry differences when it comes to firms' strategic choices, Miller and Friesen (1984) provide evidence of within-life cycle commonalties in firms' strategic and organizational design choices. Ultimately, whether incorporating life cycle results in a significant improvement in the forecast accuracy of models predicting firm growth and profitability remains an empirical question.

To assess the relative performance of life cycle models of growth and profitability, we follow Fairfield et al. (2009) and estimate first-order autoregressive models where we regress current profitability (growth) on lagged profitability (growth). Return on equity (ROE) and return on net operating assets (RNOA) are our two measures of profitability, whereas growth in sales, growth in equity, and growth in net operating assets are our measures of firm growth. We estimate these models at the economy, industry, and life cycle level and compare the out-ofsample forecast errors to investigate the relative accuracy of the life cycle model compared to the economy-wide and industry-specific models. We use Global Industry Classification Standard (GICS) codes to define industries and we use the cash flow based life cycle measure of Dickinson (2011) to capture life cycle.

We find that the life cycle model significantly outperforms the economy-wide and industry-specific models. The results are consistent across a wide range of profitability and growth measures and hold for both the mean and median level of improvement. The only exception is the life cycle-based sales growth forecast, which does not significantly improve 
upon industry-specific sales growth forecasts at the mean nor the median level. This result is consistent with Fairfield et al. (2009) who document the relative strength of industry-specific models in accurately forecasting (short-term) sales growth. Importantly, we further find that the greater forecast accuracy of the life cycle model is not limited to short-term one-year ahead forecasts, but extends to longer term forecasts as well. Specifically, we find that the life cycle model is also more accurate than the economy-wide and industry-specific models when predicting two- and three-year ahead profitability and growth metrics.

Whereas we show that on average the life cycle model outperforms both the economy-wide and the industry-specific models, we also investigate which stages the life cycle based model performs relatively better than the other models. As there are only five stages in Dickinson's (2011) life cycle classification, restricting the analyses to those stages that show the greatest improvement is an easy to implement and low-cost strategy for obtaining the most accurate forecasts. We find that the life cycle model leads to the greatest improvement in the accuracy of profitability forecasts for firms in the introduction, mature, and decline stages, both when compared to the economy-wide and industry-specific models. For firms in the growth and shakeout stages, we find that the life cycle model forecasts of RNOA and ROE are significantly less accurate than the economy-wide model forecasts and the life cycle model forecasts of ROE are significantly less accurate than the industry-specific model forecasts. When investigating the accuracy of out-of-sample growth forecasts, we find the greatest improvement for firms in the introduction, mature, shakeout and decline stages. Specifically, we find evidence of improved forecast accuracy with two (three) out of the three growth metrics for firms in the introduction and mature (shakeout and decline) stage. In line with our results for the profitability forecasts, we find weaker results for firms in the growth stage, suggesting that even though these firms are 
in the same life cycle stage, there remain considerable differences across these firms' profitability and growth dynamics.

In exploratory additional analyses, we investigate whether we can identify factors that are associated with the extent to which life cycle model-based forecasts improve upon forecasts obtained from economy-wide and industry-specific models. These tests help to provide insight into when the benefits of the life cycle model are the greatest. We find that improvements in profitability forecasts from the life cycle model are generally greater when (firm-specific) uncertainty is greater. For example, we find that improvements in the life cycle model forecast accuracy are positively associated with idiosyncratic return volatility, the standard deviation of operating performance, beta, market-to-book ratio's, R\&D intensity, intangible asset intensity, and the reporting of special items. We do not find such strong systematic evidence when investigating improvements in the accuracy of growth forecasts. However, depending on the growth measure investigated we still find some, albeit weaker, evidence of greater improvements in forecast accuracy from the life cycle model for firms with higher idiosyncratic return volatility, a higher standard deviation of operating performance, high R\&D intensity, and high intangible asset intensity. Overall, these tests suggest that the life cycle model works best in situations in which improvements in the accuracy of profitability and growth forecasts are of greater importance; i.e., when firm-specific uncertainty is high.

We further investigate whether analyst forecasts are consistent with the greater accuracy of life cycle models in predicting future profitability. We find that analyst consensus ROE forecasts have a stronger association with forecasts obtained from the life cycle model than with forecasts obtained from economy-wide or industry-specific models. However, analysts seem to only 
partially incorporate life cycle information as we also find that analyst forecast errors are positively associated with life cycle model improvements in ROE forecasts.

Our study has important implications for the financial statement analysis (FSA) literature and has the ability to inform FSA practice. Forecasts of future growth and profitability are important inputs in the valuation process. Moreover, estimates of mean reversion have important implications for determining optimal forecast horizons of accounting-based valuation models and can serve as inputs in estimating steady state terminal value parameters. As a result, it is no surprise that a substantial body of literature has been centered on identifying factors that are predictive of a firm's future profitability-generating process and developing methods to improve profitability and growth forecasts. Recognizing that profitability is shaped by a firm's economic environment, an increasing number of studies investigates the role of (innate) fundamental factors in the profitability generation process (Owens, Wu, and Zimmerman 2017; Klein and Marquardt 2006; Kim and Qi 2010; Brown and Kimbrough 2011). Historically, industry is one fundamental factor that has received considerable attention in the academic literature (Lev 1983; Hui et al. 2016; Curtis, Lundholm, and McVay 2014) as well as practice. For example, analysts often specialize in certain industries (Kadan, Madureira, Wang, and Zach 2012) and CFOs cite industry as an important factor contributing to the quality of earnings (Dichev, Graham, Harvey, and Rajgopal 2013). Yet, whereas industry-level analyses are common in both practice and academia, Fairfield et al. (2009) show that only (long-term) growth forecasts, but not profitability forecasts, are improved by industry-level analyses. However, they leave open the question as to what other factors may lead to improved (profitability) forecasts. Building on recent literature citing firm life cycle as an important factor affecting a firm's earnings generating process (Dickinson 2011), we extend this literature and find that life cycle models 
outperform economy-wide and industry-specific models in forecasting a wide range of profitability and growth metrics. Whereas, prior literature has identified (persistent) differences in profitability across the life cycle stages, our study is the first to investigate whether such differences lead to improved out-of-sample forecasts. This is an important contribution, as investigating out-of-sample forecast accuracy is informative about the usefulness of such models to FSA practice.

We further contribute to the literature on mean reversion in profitability. Previous studies have investigated multiple factors that affect the degree of mean reversion, including firm characteristics (Nissim and Penman 2001), industry factors (Fairfield et al. 2009), and country characteristics (Healy, Serafeim, Srinivasan, and Yu 2014). We extend this literature by investigating the role of firm life cycle and documenting its usefulness for out-of-sample forecasting.

The remainder of the paper is organized as follows. In the next section, we discuss the role of firm life cycle in accounting measurement and we discuss how we believe it can be relevant in a forecasting setting. Section III discusses the research design. In section IV, we present the main results and finally section $\mathrm{V}$ concludes.

\section{LIFE CYCLE AND FORECASTING}

Whereas it is well known that profitability and growth exhibit mean reversion, how best to model such mean reversion remains an open question. Although economy-wide mean-reverting models would suffice if all firms in the economy were similar, differences across firms suggests that forecast accuracy can be improved by estimating such models on groups of similar firms. Despite the considerable differences across firms in different industries, the findings of Fairfield et al. (2009) suggest that a lack of within-industry homogeneity prevents a meaningful 
improvement in the accuracy of (profitability) forecasts and limits the usefulness of an industryspecific model. We propose the use of a life cycle model as an alternative way of estimating mean-reversion to improve short-term and long-term profitability and growth forecasts.

A common limitation of both economy-wide and industry-specific models is that they treat firms as static entities, ignoring the dynamic environment in which firms develop over time. Firm life cycle, arising from a combination of internal factors, such as firms' strategic choices, and external factors, such as the competitive pressures firms face, is a multifaceted construct that reflects these distinct phases of firm development (Hanks, Watson, Jansen, and Chandler 1993). In a typical life cycle classification, such as that from Gort and Klepper (1982), firms can be in one of five different stages, introduction, growth, maturity, shakeout, or decline, through which they can move in a non-sequential manner (Miller and Friesen 1984). As firms move through the life cycle stages, many of the underlying factors change simultaneously, reflecting the interdependencies that exist among them. ${ }^{1}$

Studies in the organization literature have since long argued that organizational behavior is predictable using organizational life cycle models (Miller and Friesen 1984). For example, Milliman, Von Glinow, and Nathan (1991) investigate how international human resource management practices vary over the organizational life cycle, whereas Quinn and Cameron (1983) argue that the criteria for evaluating organizational effectiveness vary with life cycle stage. Similarly, Koberg, Uhlenbruck, and Sarason (1996) find that to facilitate innovation, organizations at different stages of development require different organizational structures. Other studies have focused on internal and external pressures, opportunities, and threats and have used firm life cycle to explain variation in factors such as the importance of various stakeholder

\footnotetext{
${ }^{1}$ These interdependencies further illustrate the importance of the life cycle concept. Whereas many aspects can be observed from looking at individual variables, life cycle is more than the sum of its parts and captures how a multitude of factors work together to achieve a variety of organizational outcomes.
} 
groups (Jawahar and McLaughlin 2001), problems faced by managers (Kazanjian 1988), and top-management priorities (Smith, Mitchell, and Summer 1985).

As illustrated by the studies above, firms in different life cycle stages exhibit vast differences in the challenges and opportunities they face and as a result have different organizational structures and behave differently. As such, each life cycle stage differs from each other and is a unique, multifaceted, aggregation of environmental factors, strategies, organizational design decisions, and corporate behavior (Miller and Friesen 1984). These differences are also reflected in the earnings generating process of firms in different life cycle stages. Many of the factors affected by firm life cycle relate to the very nature in which firms do business and thus have implications for their current and future performance. Dickinson (2011) shows that differences in average profitability across the life cycle stages are substantial and persistent. From a forecasting perspective these findings suggest that mean reversion differs across life cycle stages, such that a mean-reverting model based on life cycle stages should lead to greater forecast accuracy.

However, heterogeneity across life cycle stages is not sufficient to generate accurate forecasts. Estimating mean-reverting models by life cycle stage further assumes that firms within a life cycle stage are homogeneous. Importantly, Miller and Friesen (1984) suggest that firms within a life cycle stage are similar as the "relationships among strategy, structure, and situation are integral and produce the common profiles of the five life-cycle phases." As such, these findings provide further support for the benefits of a life cycle-based mean-reverting model. However, whereas firms within a life cycle stage are similar, firms can still go through the phases in entirely different sequences and can remain in a life cycle stage for different lengths of time (Miller and Friesen 1984; Quinn and Cameron 1983). For example, whereas some firms 
will go from a mature phase to a decline phase, some will stay in the mature stage for a considerable time, and others are able to re-invent themselves and enter another period of growth. Naturally, the sequence by which firms move through the life cycle stages will have substantial performance consequences. Thus, despite the differences across the life cycle stages and the similarities between firms within a life cycle stage, life cycle models may not lead to greater forecast accuracy, as there are substantial differences in the way in which firms move through the different phases. Ultimately, whether a life cycle model improves the accuracy of firm growth and profitability forecasts remains an empirical question.

\section{RESEARCH DESIGN}

To investigate the usefulness of a life cycle model, we investigate the out-of-sample forecast errors of models predicting measures of firm growth and firm profitability. Following Fairfield et al. (2009) we forecast three measures of firm growth: growth in sales (GSALE), growth in net operating assets $(G N O A)$, and growth in the book value of common equity $(G C E Q)$. For all three growth measures, we calculate the percentage change from the previous to the current year. Net operating assets is defined as the sum of common stock (Compustat CEQ), preferred stock (Compustat PSTK), long-term and short-term debt (Compustat DLTT + DLC), and minority interest (Compustat MIB), less cash and short-term investments (Compustat CHE). We use return on equity $(R O E)$, measured as income before extraordinary items available to common stockholders (Compustat IBC) scaled by average common shareholders' equity, and return on net operating assets (RNOA), measured as operating income (Compustat OIADP) scaled by average net operating assets, as our measures of profitability.

To capture firm life cycle we use the cash flow based proxy developed in Dickinson (2011), who assigns firms into five different stages, Introduction, Growth, Maturity, Shakeout, 
and Decline. As the measure is based on systematic cash flow patterns that are observed for firms in different life cycle stages, consistent with life cycle theory (Miller and Friesen 1984), it allows firms to move through the stages in a non-sequential manner and allows for variation in the time firms spend in each stage. ${ }^{2}$ Following prior literature (Bhojraj, Lee, and Oler 2003; Hui et al. 2016), we use global Industry Classification Standard (GICS) codes to define industry. In the main tests, we use the six-digit GICS industry codes, but our results are similar using eightdigit GICS sub-industry codes. ${ }^{3}$

To investigate the relative out-of-sample forecast accuracy of the economy-wide, industryspecific, and life cycle models, we estimate, for each year $t$, mean-reverting models using a rolling regression window on data from the preceding 10 years. Our holdout sample starts in 1998 and ends in 2015. Since we rely on cash flow patterns to assign firms to the life cycle stages, we start the holdout sample in 1998 as this is the first year for which we have 10 years of available data to measure firm life cycle and estimate in-sample life cycle models. We include all nonfinancial firms with available data to calculate the growth and profitability variables. Following Fairfield et al. (2009), we exclude firm-years in which lagged sales or lagged net operating assets are less than $\$ 10$ million, and firm-years in which lagged book value of common

\footnotetext{
${ }^{2}$ More specifically, we use the following classification table to assign firm-year observations to the distinct life cycle stages (retrieved from: Dickinson 2011, p. 1974):

\begin{tabular}{|c|c|c|c|c|c|c|c|c|}
\hline \multirow[b]{3}{*}{ Cash Flow Type } & \multicolumn{8}{|c|}{ Life Cycle Stages } \\
\hline & \multirow{2}{*}{$\begin{array}{c}\text { Introduction } \\
1 .\end{array}$} & \multirow{2}{*}{$\begin{array}{c}\text { Growth } \\
2 .\end{array}$} & Mature & \multicolumn{3}{|c|}{ Shake-Out } & \multicolumn{2}{|c|}{ Decline } \\
\hline & & & 3. & 4. & 5. & 6. & 7. & 8. \\
\hline Operating Activities & - & + & + & - & + & + & - & - \\
\hline Investing Activities & - & - & - & - & + & + & + & + \\
\hline Financing Activities & + & + & - & - & + & - & + & - \\
\hline
\end{tabular}
}

One could further argue that firms with negative operating cash flows and positive cash flows from investing and financing activities (\#7) should be classified as growth firms. Results are robust to using this alternative classification.

${ }^{3}$ In untabulated tests, we further find that the results are similar when we use GICS sector codes, GICS subindustry codes, two-digit historical SIC codes, historical NAIC codes, or a text-based industry measure based on the similarity of firms' product market descriptions in 10-K's (Hoberg and Phillips 2010, 2016). 
equity is less than $\$ 1$ million. In the estimation sample, we further exclude firms with absolute ROE or RNOA greater than one, and growth measures over $100 \%$, and we truncate the two profitability and three growth measures at the $1 \%$ and $99 \%$ level. To avoid a look-ahead bias, we do not truncate any of the variables in the holdout sample and exclude firms with lagged absolute ROE or RNOA greater than one, and lagged growth measures over $100 \%{ }^{4}$

After applying the above-mentioned data screens, we are left with 60,536 firm-years, which we use to estimate economy-wide, industry-specific, and life cycle first-order autoregressive models. For the economy-wide model, we pool all firms in a year, whereas for the life cycle and industry-specific model we estimate separate regressions per life cycle-year and industry-year, respectively. It is important to note that we estimate these models based on a firm's industry and life cycle in year $t-1$. To classify a firm in a life cycle stage in year $t$ would require us to have realized cash flow data from year $t$ and would thus create a look-ahead bias. Hence, to avoid such a look-ahead bias in our investigation of out-of-sample forecast accuracy, we use a firm's lagged life cycle and industry classification as the basis for our tests.

Economy-wide: $\quad G R O W T H_{\mathrm{i}, \mathrm{t}}=\alpha_{\mathrm{t}}+\beta_{\mathrm{t}} G R O W T H_{\mathrm{i}, \mathrm{t}-1}+\varepsilon_{\mathrm{i}, \mathrm{t}}$ Industry-specific: $\quad G R O W T H_{\mathrm{i}, \mathrm{t}}=\alpha_{\mathrm{ind,t}}+\beta_{\mathrm{ind}, \mathrm{t}} G R O W T H_{\mathrm{i}, \mathrm{t}-1}+\varepsilon_{\mathrm{i}, \mathrm{t}}$ Life Cycle: $\quad G R O W T H_{\mathrm{i}, \mathrm{t}}=\alpha_{\mathrm{lc}, \mathrm{t}}+\beta_{\mathrm{lc}, \mathrm{t}} G R O W T H_{\mathrm{i}, \mathrm{t}-1}+\varepsilon_{\mathrm{i}, \mathrm{t}}$

where GROWTH is either GSALE, GNOA, or GCEQ. In the estimation of our mean-reverting profitability models, we further distinguish between profitable and loss-making firms. There is considerable evidence that losses are less persistent and less informative about firms' future

\footnotetext{
${ }^{4}$ The results are robust to truncating the (year $t$ or $t-1$ ) growth and profitability measures in the holdout sample as well.
} 
performance (Hayn 1995). As such, we can expect mean reversion to differ between profitable and unprofitable firms. Specifically, we estimate the following profitability models:

Economy-wide: $\quad$ PROFIT $_{\mathrm{i}, \mathrm{t}}=\alpha_{\mathrm{t}}+\beta_{\mathrm{t}} P R O F I T_{\mathrm{i}, \mathrm{t}-1}+\gamma_{\mathrm{t}} N E G_{\mathrm{i}, \mathrm{t}-1}+\lambda_{\mathrm{t}} N E G_{\mathrm{i}, \mathrm{t}-1} * P_{R O F I T_{\mathrm{i}, \mathrm{t}-1}}+\varepsilon_{\mathrm{i}, \mathrm{t}}$, Industry-specific: $: \quad P R O F I T_{\mathrm{i}, \mathrm{t}}=\alpha_{\mathrm{t}}+\beta_{\text {ind, } \mathrm{P}}$ PROFIT $_{\mathrm{i}, \mathrm{t}-1}+\gamma_{\text {ind, } \mathrm{t}} N E G_{\mathrm{i}, \mathrm{t}-1}+\lambda_{\text {ind,t }} N E G_{\mathrm{i}, \mathrm{t}-\mathrm{1}} * P R O F I T_{\mathrm{i}, \mathrm{t}-1}$ $+\varepsilon_{\mathrm{i}, \mathrm{t}}$

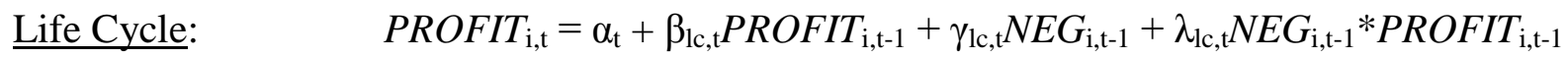
$+\varepsilon_{\mathrm{i}, \mathrm{t}}$

where PROFIT is either RNOA or ROE, and NEG is an indicator variable that is equal to one if operating income (in the RNOA regressions), or income before extraordinary items (in the $R O E$ regressions), is negative, and zero otherwise. In the estimation of both the growth and profitability models, we require a minimum of 100 observations per year, industry and year, or life cycle and year, for the economy-wide, industry-specific, and life cycle models, respectively.

\section{RESULTS}

\section{Descriptive Statistics}

Table 1 reports the descriptive statistics of the in-sample firm years, both overall (Panel A), as well as means (Panel B) and standard deviations (Panel C) per (lagged) life cycle stage. Average growth rates range from $6.00 \%$ for growth in the book value of equity to $7.74 \%$ for growth in sales. Mean RNOA is equal to $12.86 \%$, well above the average ROE of $5.90 \%$, driven by the exclusion of non-operating items. Moving to the descriptive statistics per life cycle, we find that, consistent with prior literature, profitability is lowest for firms in the introduction and decline stage and peaks for firms in the mature stage. However, average profitability is higher than in 
Dickinson (2011), potentially driven by our requirement to have contemporaneous and lagged data available for estimating mean reversion in profitability and growth parameters. Not surprisingly, growth measures peak for firms in the growth stage, with growth in sales, net operating assets, and book equity being $11.34 \%, 10.16 \%$, and $8.50 \%$, respectively. These percentages are lower than in Dickinson (2011), probably driven by our requirement that growth be less than $100 \%$ and the deletion of firms with lagged sales and net operating assets of less than $\$ 10$ million (rather than $\$ 1$ million in (Dickinson 2011)).

[Table 1 about here]

From the standard deviations reported in Panel C, we observe that within a life cycle, variation in firm growth and profitability is greatest in the introduction and decline stages and lowest for firms in the mature stage. As out-of-sample forecast error improvements crucially depend on firms within a group being similar, these higher standard deviations suggest that improvements may be weaker or absent for firms in the introduction and decline stages. However, this may be compensated by the fact that the difference between sample-wide average growth and profitability and average growth and profitability in the life cycle stage is generally larger for the introduction and decline stages.

Panel D reports the Pearson (top) and Spearman (bottom) correlations over the in-sample estimation period. We find correlations that are comparable to those in Fairfield et al. (2009), with the highest correlations between $R N O A$ and $R O E$ as well as between their contemporaneous and lagged values. Correlations between the growth measures are approximately 0.40 . The correlations between the growth measures and the profitability measures are generally lower with the exception of the growth in equity and return on equity, which have a correlation of 0.61 . 


\section{In-Sample Estimation}

Table 2 reports the results of the in-sample estimation of the mean-reverting models of firm growth and firm profitability. The reported coefficients and the associated t-statistics are calculated following Fama and MacBeth (1973). For the economy-wide model, the reported coefficient is equal to the average of the 18 yearly coefficients. For the life cycle (industryspecific) model, we first calculate average yearly coefficient estimates across the life cycle stages (industries), and then report the mean of those 18 yearly average coefficients.

[Table 2 about here]

With respect to our growth measures, we find that the growth in the book value of equity is the most persistent. However, for all our growth measures we find only moderate levels of persistence, as the slope coefficients range between 0.15 and 0.27 . In line with prior literature, we find higher persistence levels in our profitability models (Freeman, Ohlson, and Penman 1982), with average slope coefficients on $R N O A$ and $R O E$ ranging between 0.65 and 0.83 , depending on the model used. We further find considerably lower persistence in $R N O A$ and $R O E$ for loss firms. The average coefficients on the interaction of $N E G$ and $R N O A$ are between -0.26 and -0.31 and are highly significant, implying an average slope coefficient for firms with negative RNOA of approximately 0.50 . Differentiating between profit and loss firms is even more important in the models of $R O E$, as the average coefficient on the interaction of $N E G$ and $R O E$ lies between -0.40 and -0.53 and the slope coefficient for firms with negative $R O E$ is only approximately 0.30 .

\section{Improvements in Out-of-Sample Forecast Accuracy}


Table 3 reports the results of the tests comparing the out-of-sample forecast accuracy of the economy-wide, industry-specific, and life cycle models for the three growth measures and the two profitability measures in our holdout sample of 40,466 firm-years. We first obtain predicted growth (profitability) by using the in-sample coefficient estimates from the 10 years up to year $t$ 1 and multiply those with realized growth (profitability) of year $t$ - 1 , to predict growth (profitability) in year $t$. We then compare actual growth and profitability in year $t$ with its predicted value to obtain the absolute out-of-sample forecast error:

\begin{tabular}{|c|c|c|}
\hline Economy-wide: & $G R O W T H \_A F E_{E W}$ & $=\left|G R O W T H_{\mathrm{i}, \mathrm{t}}-\mathrm{E}_{\mathrm{EW}}\left(G R O W T H_{\mathrm{i}, \mathrm{t}}\right)\right|$ \\
\hline Industry-specific: & $G R O W T H \_A F E_{I N D}$ & $=\left|G R O W T H_{\mathrm{i}, \mathrm{t}}-\mathrm{E}_{\mathrm{IND}}\left(G R O W T H_{\mathrm{i}, \mathrm{t}}\right)\right|$, \\
\hline Life Cycle: & $G R O W T H \_A F E_{L C}$ & $=\left|G R O W T H_{\mathrm{i}, \mathrm{t}}-\mathrm{E}_{\mathrm{LC}}\left(G R O W T H_{\mathrm{i}, \mathrm{t}}\right)\right|$, \\
\hline Economy-wide: & $P R O F I T \_A F E_{E W}$ & 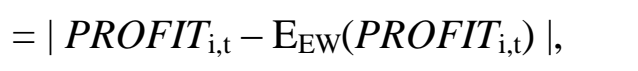 \\
\hline Industry-specific: & $P R O F I T \_A F E_{I N D}$ & $=\left|P R O F I T_{\mathrm{i}, \mathrm{t}}-\mathrm{E}_{\mathrm{IND}}\left(P R O F I T_{\mathrm{i}, \mathrm{t}}\right)\right|$ \\
\hline Life Cycle: & PROFIT_AFE $E_{L C}$ & $=\left|P R O F I T_{\mathrm{i}, \mathrm{t}}-\mathrm{E}_{\mathrm{LC}}\left(P R O F I T_{\mathrm{i}, \mathrm{t}}\right)\right|$, \\
\hline
\end{tabular}

where GROWTH is GSALE, GNOA, or GCEQ, PROFIT is RNOA or ROE, and $\mathrm{E}_{\mathrm{EW}}\left(G R O W T H_{\mathrm{i}, \mathrm{t}}\right), \mathrm{E}_{\mathrm{IND}}\left(G R O W T H_{\mathrm{i}, \mathrm{t}}\right)$, and $\mathrm{E}_{\mathrm{LC}}\left(G R O W T H_{\mathrm{i}, \mathrm{t}}\right)$ is the forecasted growth using the economy-wide, industry-specific, and life cycle model, respectively, and $\mathrm{E}_{\mathrm{EW}}\left(P R O F I T_{\mathrm{i}, \mathrm{t}}\right)$, $\mathrm{E}_{\mathrm{IND}}\left(P R O F I T_{\mathrm{i}, \mathrm{t}}\right)$, and $\mathrm{E}_{\mathrm{LC}}\left(P R O F I T_{\mathrm{i}, \mathrm{t}}\right)$ is the forecasted profitability using the economy-wide, industry-specific, and life cycle model, respectively. To investigate whether the life cycle model produces more accurate out-of-sample forecasts, we calculate paired forecast improvements. Specifically, for each firm-year we compare the growth forecast error of the life cycle model to the forecast error from the economy-wide $\left(G R O W T H_{-} A F E_{E W}-G R O W T H \_A F E_{L C}\right)$ and the 
industry-specific model $\left(G R O W T H \_A F E_{I N D}-G R O W T H \_A F E_{L C}\right)$ and the profitability forecast error of the life cycle model to the forecast error from the economy-wide (PROFIT_AFE $E_{E W}-$ PROFIT_AFE $\left.E_{L C}\right)$ and the industry-specific model $\left(P R O F I T \_A F E_{I N D}-P R O F I T \_A F E_{L C}\right)$. We construct these variables such that a positive value indicates that the life cycle model forecast is more accurate. We then calculate, for each year, the mean and median level of improvement for each of the model comparisons and test whether the improvements are significant by investigating whether the grand mean (median) across the 18 years is significant based on t-tests (Wilcoxon signed-rank tests). We further show the number of years (out of 18) in which the annual mean and median are significantly positive/negative (at the $10 \%$ level in two-tailed tests).

The results reported in Table 3 provide strong evidence that the life cycle model outperforms the economy-wide and industry-specific models when forecasting year-ahead growth and year-ahead profitability. When we compare the forecast error of the life cycle model to the forecast error of the economy-wide model, we find that the mean improvement of the life cycle model is significantly positive for all three growth measures and both profitability measures. The median level of improvement is significantly positive for GSALE as well as both profitability measures. In addition, we find that the number of years in which the life cycle model improves mean and median forecast accuracy is large. For example, the mean (median) improvement of $R N O A$ and $R O E$ forecasts is significantly positive in 7 and 17 (12 and 17) out of the 18 years, respectively. In none of the years is there a significant reduction in forecast accuracy. We obtain similar results with the growth measures where, with the exception of the median improvement in GNOA forecasts, there is a significant improvement in at least 11 out of the 18 years.

[Table 3 about here] 
When investigating the forecast accuracy of the life cycle model compared to the industryspecific model, we find that the life cycle model improves the forecast accuracy of models predicting GNOA, GCEQ, RNOA, and ROE. Both the mean and the median improvement are significant at the 5 percent level or better. In addition, we find that life cycle model forecasts are significantly more accurate at the mean and the median level in at least 10 out of the 18 years, across all these measures. In addition, with the exception of the median improvement in $G C E Q$, life cycle model forecasts are never significantly less accurate than forecasts obtained from industry-specific models. We do not find a significant improvement at the mean nor the median level for the accuracy of sales growth forecasts (GSALE). Although the coefficients are positive and the number of years in which life cycle model forecasts are significantly more accurate is greater than the number of years in which they are significantly less accurate $(8 / 3$ and $5 / 2$ for the mean and median improvement, respectively), the improvements are not statistically significant. This result is consistent with Fairfield et al. (2009) who find that the industry-specific model performs well in predicting year-ahead sales growth. Overall, the results reported in this section show that the life cycle model produces more accurate forecasts of future growth and future profitability than the economy-wide and industry-specific models.

\section{Improvements by Life Cycle Stage}

Thus far, we have shown that, on average, life cycle model forecasts are more accurate than forecasts obtained from economy-wide and industry-specific models. In this section, we investigate whether these results differ conditional on a firm's life cycle stage. To find improvements in out-of-sample forecast accuracy it is important that we separate groups of firms with different characteristics, whereas the firms within a group should be similar. It is possible that this is true for some life cycle stages, but not for others. For example, the homogeneity 
assumption may apply well to stable firms in the mature stage, but may be less applicable to a group of growth firms in which each may grow at a different rate. Similarly, separating introduction and decline firms from the more stable firms that make up the economy or the industry may lead to improved forecast accuracy, but may also lead to decreased forecast accuracy if these firms follow entirely different growth and profitability patterns. For example, the descriptive statistics we have reported previously show that mean growth and profitability in the introduction and decline stage deviate substantially from the economy-wide average suggesting that separating firms in those life cycle stages may lead to improved forecast accuracy. However, the relatively high within-life cycle standard deviation of growth and profitability in those stages suggests that there are considerable differences across firms, potentially limiting the usefulness of the life cycle model for such firms. Ultimately, in which stages the life cycle model performs best remains an empirical question, which we address in this section.

\section{[Table 4 about here]}

The results of these tests are reported in Table 4. Panel A reports the results of investigating the improvement by life cycle, comparing the life cycle model to the economy-wide model. With respect to the profitability forecasts, we find that they are significantly more accurate for firms in the introduction, mature, and decline stage, and significantly less accurate for firms in the growth and shakeout stage. With respect to the growth forecasts, we find significant improvement for three (two) out of three measures for firms in the shakeout and decline (introduction and mature) stage. We further find that forecasts of GSALE are less accurate for firms in the introduction stage and that forecasts of GNOA are less accurate for firms in the mature stage. Consistent with the results for the profitability forecasts, we find that the results are weakest for firms in the 
growth stage. Overall, these results suggest that the life cycle model performs well for firms in most of the life cycle stages, with the exception of firms in the growth stage where we do not find significant improvement in the accuracy of growth forecasts, and significantly less accurate profitability forecasts.

As can be seen from the results reported in Panel B, a similar pattern emerges when we compare the life cycle model to the industry-specific model. For the profitability forecasts, we again find the greatest improvements for firms in the introduction, mature, and decline stage. Results are weaker for firms in the growth and shakeout stages. However, in contrast to the comparison to the economy-wide forecasts, in which the life cycle profitability forecasts are less accurate for firms in these stages, we find that the life cycle RNOA forecasts are more accurate and $R O E$ forecasts are of comparable accuracy relative to the industry-specific forecasts. With respect to the growth forecasts, we find significant improvements for three (two) out of three measures for firms in the shakeout and decline (introduction and mature) stage. However, in contrast to the comparison to the economy-wide model, in which the life cycle GSALE and GNOA forecasts are less accurate for firms in the introduction and mature stage respectively, we find that they are of comparable accuracy to forecasts obtained from industry-specific model.

Overall, the results reported in this section show that the life cycle model generates forecasts that are more accurate for firms in most of the life cycle stages, with the exception of firms in the growth stage for which we do not find a consistent pattern of improvements in forecast accuracy. These findings suggest that even though firms in the growth stage may be different from firms in the other stages, heterogeneity across firms in the growth stage is too high to lead to substantial improvements in forecast accuracy for these firms.

\section{Combining Industry and Life Cycle}


The results reported thus far indicate that life cycle model forecasts are more accurate than forecasts obtained from economy-wide and industry-specific models. As such, these findings are consistent with Fairfield et al. (2009) and provide additional evidence for the limited role of industry information for out-of-sample forecasting. However, whereas industry in isolation may be of limited importance, it could be that forecasts obtained from a model that combines industry and life cycle information are more accurate than forecasts obtained from models than only incorporate life cycle or industry. Hence, we also investigate the out-of-sample forecast accuracy of a mean-reverting model estimated per industry, year, and life cycle. To have a sufficient number of observations within each group, we use two-digit GICS sector codes to define industries. The results (untabulated) indicate that forecasts from a model that combines industry and life cycle generally are more accurate than forecasts from the economy-wide and industryspecific models. However, compared to forecasts obtained from the life cycle model, we find that fewer forecast improvements are statistically significant, both when we look at the grand mean or median as well as the number of individual years with significant improvements in forecast accuracy. Overall, these results suggest that estimating mean-reverting models by life cycle produces more accurate out-of-sample forecasts than models that combine industry and life cycle.

\section{Long-Term Forecast Accuracy}

In addition to investigating one-year ahead forecast accuracy, we investigate forecast accuracy over longer horizons. Table 5 reports the improvements in two- and three-year ahead forecast accuracy. To investigate the accuracy of growth forecasts, we define our growth measures as the compounded growth rate over a two- or three-year period. Similarly, we use two- and three-year ahead $R N O A$ and $R O E$ to investigate the accuracy of long-term profitability forecasts. To avoid a 
look-ahead bias we use two- and three-year lagged life cycle and industry classifications in these tests.

With respect to the two-year ahead forecast accuracy reported in Panel A, we continue to find that the life cycle model forecasts are more accurate than forecasts from the economy-wide and industry-specific models. We generally find significant improvements in forecast accuracy, both at the mean and the median level. Furthermore, we find that the improvements are significantly positive in the majority of years, whereas there are only few years in which the forecasts from the life cycle model are significantly less accurate. Consistent with the results reported previously, we do not find significant improvements in future sales growth forecasts when we compare the life cycle model to the industry-specific model.

\section{[Table 5 about here]}

The results for three-year ahead forecast accuracy reported in Panel B show that, when compared to the economy-wide model, the life cycle model forecasts are more accurate for all growth measures and both profitability measures. Moreover, the annual improvements are positive and significant in at least 10 out of the 18 years, with the exception of improvements in sales growth forecasts that are significantly positive in at least six years. Compared to the industry-specific model, we find weaker evidence of improvements in three-year ahead growth forecasts as only the mean improvement in GNOA forecasts is significantly positive. However, we continue to find that the number of years in which life cycle model forecasts are more accurate is considerably higher than the number of years in which they are less accurate.

For the profitability forecasts, we continue to find strong evidence of significant improvements in forecast accuracy with the life cycle model, where only the mean improvement 
in $R N O A$ is positive but not significant. ${ }^{5}$ Moreover, we find that the annual mean (median) improvement is positive and significant in 14 (9) out of the 18 years when we investigate $R N O A$ forecasts and 15 (13) out of the 18 years when we investigate $R O E$ forecasts. Taken together, the results suggest that the greater accuracy of the life cycle model forecasts is not limited to oneyear ahead forecasts, but extends to two- and three-year ahead forecasts as well. Furthermore, the life cycle model seems to particularly improve upon the economy-wide and industry-specific model when it comes to forecasting long-term profitability.

\section{Factors Associated with Forecast Accuracy Improvements}

This section reports the results of some exploratory analyses in which we investigate whether we can identify factors that are associated with the extent to which the life cycle model improves forecasts relative to the economy-wide or industry-specific models. Although the tests reported so far indicate that the life cycle model on average performs better than the economy-wide and industry-specific models, we can gain important insights into the benefits of the life cycle model by investigating firm characteristics that are associated with improvements in forecast accuracy. Specifically, we estimate the following model:

$$
\begin{aligned}
& \text { IMPROVEMENT }_{\mathrm{i}, \mathrm{t}}=\beta_{0}+\beta_{1} \text { STD_IDIORET }_{\mathrm{i}, \mathrm{t}-1}+\beta_{2} \text { STDROA }_{\mathrm{i}, \mathrm{t}-1}+\beta_{3} \text { ABNRET }_{\mathrm{i}, \mathrm{t}-1}+\beta_{4} \text { TVOL }_{\mathrm{i}, \mathrm{t}-1}+ \\
& \beta_{5} \text { BETA }_{\mathrm{i}, \mathrm{t}-1}+\beta_{6} \text { INSTH }_{\mathrm{i}, \mathrm{t}-1}+\beta_{7} \text { ANALYST }_{\mathrm{i}, \mathrm{t}-1}+\beta_{8} \text { MTB }_{\mathrm{i}, \mathrm{t}-1}+\beta_{9} \text { SIZE }_{\mathrm{i}, \mathrm{t}-1}+\beta_{10} \text { LEVERAGE }_{\mathrm{i}, \mathrm{t}-1}+ \\
& \beta_{11} \text { RDINT }_{\mathrm{i}, \mathrm{t}-1}+\beta_{12} \text { PPEINT }_{\mathrm{i}, \mathrm{t}-1}+\beta_{13} \text { INTANINT }_{\mathrm{i}, \mathrm{t}-1}+\beta_{14} S P E C I A L_{\mathrm{i}, \mathrm{t}-1}+\varepsilon_{\mathrm{i}, \mathrm{t}}
\end{aligned}
$$

where IMPROVEMENT is the improvement in the accuracy of the two profitability and three growth forecasts from the life cycle model relative to the forecasts from the economy-wide or industry-specific model. As can be seen from the regression equation, to investigate the accuracy

\footnotetext{
${ }^{5}$ Although the grand mean of 18 average annual improvements is not significant, we find that the overall mean is positive and highly significant.
} 
of out-of-sample forecasts, we estimate all factors prior to the year for which we measure the improvement in forecast accuracy. STD_IDIORET is the standard deviation of daily market model residual returns and captures a firm's idiosyncratic risk which has been shown to be important in accounting settings (Mashruwala, Rajgopal, and Shevlin 2006). We use CRSP's value weighted return as the market return and estimate STD_IDIORET over the one-year period from the fourth month after the start of the fiscal year to the third month after the fiscal year-end. STDROA is the standard deviation of quarterly return on assets $\left(\mathrm{IBQ}_{\mathrm{t}} / \mathrm{ATQ}_{\mathrm{t}-1}\right)$, measured over 20 quarters and requiring a minimum of 8 quarters, and is directly related to the difficulty in forecasting future profitability. ABNRET is the firm's 12-month abnormal return, where we subtract CRSP's value weighted market return from the firm's return to calculate abnormal returns. TVOL is the 12-month sum of monthly trading volume scaled by shares outstanding (VOL / SHROUT). BETA is the coefficient on market returns of a regression of firm returns on CRSP's value-weighted returns and captures systematic risk. ABNRET, TVOL, and BETA are all calculated over the same one-year window that we use to calculate STD_IDIORET. ANALYST is the number of analysts issuing annual earnings forecasts in I/B/E/S and INSTH is the percentage of shares owned by institutions based on the Thomson Reuters' Institutional Holdings (13f) database. $M T B$ is the market-to-book ratio (PRCC_F * CSHO / CEQ). SIZE is the natural logarithm of total assets and LEVERAGE is total debt over total assets (DLC + DLTT / AT). We further include $\mathrm{R} \& \mathrm{D}$ intensity $\left(R D I N T=\mathrm{XRD}_{\mathrm{t}} / \mathrm{AT}_{\mathrm{t}-1}\right), \mathrm{PPE}$ intensity $(P P E I N T=\mathrm{PPENT} / \mathrm{AT})$, and intangible asset intensity $($ INTANINT $=$ INTAN / AT $)$. Finally, we include SPECIAL, which is an indicator variable for whether the firm reports special items (abs[SPI] >0), as special items can impact earnings persistence and thus have implications for earnings forecasting (Dechow and Ge 2006). For the purpose of this test, we cluster standard errors at the firm level. 
[Table 6 about here]

The results are reported in Table 6. Panel A shows the results of the tests in which we investigate the improvement in profitability forecasts. We find that the improvement in the accuracy of profitability forecast is generally greater for firms that have greater uncertainty, both compared to the economy-wide model as well as the industry-specific model. For example, we find that improvements in forecast accuracy are positively associated with idiosyncratic risk, the standard deviation of operating performance, systematic risk, the market-to-book ratio, R\&D intensity, and intangible asset intensity. Furthermore, we find some evidence that forecast improvements are stronger for firms that are less visible. Specifically, we find a negative and significant relation between forecast improvements and institutional ownership (trading volume) in three (one) out of the four specifications. We do not find evidence of differences in improvements conditional on analyst following. Finally, we find that improvements are greater for firms that reported special items, suggesting that life cycle models are better able to incorporate the future performance effects of one-time non-persistent items. Not surprisingly, these results are stronger when we investigate the relative accuracy of ROE forecasts as RNOA uses operating income, which excludes special items.

Panel B shows the results of the tests investigating forecast improvements in growth forecasts. The results are generally weaker and depend on the growth measure that we investigate. However, we still find a positive and significant association between forecast improvements and idiosyncratic risk, the standard deviation of operating performance, $R \& D$ intensity, and intangible asset intensity in at least three out of the six specifications. Moreover, we find that improvements in growth forecasts are generally more accurate for firms with lower returns and we continue to find some evidence that the improvements are greater for firms with 
lower visibility as evidenced by the negative and significant association between IMPROVEMENT and INSTH in three of the specifications.

To summarize, in this section we have reported the results of some exploratory analyses in which we investigate factors that are associated with the extent to which forecasts from a life cycle model are more accurate than forecasts obtained from economy-wide and industry-specific models. Although the results are generally stronger for profitability forecasts, the general pattern that emerges from these tests is that improvements are greater for less visible firms with greater uncertainty.

\section{Model ROE Forecasts and Analyst ROE Forecasts}

Our results thus far indicate that mean reversion in profitability can best be modeled as a function of firm life cycle. In this section, we investigate whether analyst profitability forecasts are consistent with the greater accuracy of life cycle models. Fairfield et al. (2009) find that, consistent with the limited ability of industry to explain mean reversion in firm profitability, analyst ROE forecasts are less closely associated with ROE forecasts from industry models. Whereas the fact that analysts specialize by industry suggests that they should be able to recognize situations in which industry-level analyses are beneficial or not, it is ex-ante less clear whether the same holds for their ability to recognize the benefits of life cycle analyses. Hence, in this section we perform two tests in which we investigate the extent to which analyst ROE forecasts reflect the improved accuracy of life cycle models. Following Fairfield et al. (2009), we first examine the association between sell-side analyst ROE forecasts and ROE forecasts obtained from the economy-wide, industry-specific, and life cycle models. If analysts recognize the benefits of life cycle analyses, we expect analyst forecasts to be more strongly associated 
with life cycle model ROE forecasts. To investigate the association between analyst and model ROE forecasts, we estimate the following regressions:

$A N A L Y S T \_R O E_{\mathrm{i}, \mathrm{t}}=\beta_{0}+\beta_{1} P R E D \_E W_{-} R O E_{\mathrm{i}, \mathrm{t}}+\varepsilon_{\mathrm{i}, \mathrm{t}}$

$A N A L Y S T \_R O E_{\mathrm{i}, \mathrm{t}}=\beta_{0}+\beta_{1} P R E D \_I N D \_R O E_{\mathrm{i}, \mathrm{t}}+\varepsilon_{\mathrm{i}, \mathrm{t}}$

$A N A L Y S T \_R O E_{\mathrm{i}, \mathrm{t}}=\beta_{0}+\beta_{1} P R E D \_L C \_R O E_{\mathrm{i}, \mathrm{t}}+\varepsilon_{\mathrm{i}, \mathrm{t}}$

where ANALYST_ROE is either the first or last consensus (mean) analyst ROE forecast in I/B/E/S and PRED_EW_ROE, PRED_IND_ROE, and PRED_LC_ROE, are forecasts obtained from the economy-wide, industry-specific, and life cycle model, respectively. ${ }^{6}$ The first forecast is defined as the first consensus forecast in $\mathrm{I} / \mathrm{B} / \mathrm{E} / \mathrm{S}$ for year $t$, issued after the announcement of year $t-1$ earnings. The last forecast is defined as the last forecast issued prior to the announcement of year $t$ earnings. We use a Vuong test to compare the R-Squares of the regression models and investigate the relative association of analyst forecasts with the respective model forecasts. The final sample consists of 18,661 firm-years with available model and analyst ROE forecasts.

The results are reported in Table 7, Panel A. When investigating the first forecast, we find that economy-wide, industry-specific, and life cycle models explain on average $52.04 \%$, $51.42 \%$, and $53.25 \%$ of the variation in analyst ROE forecasts. Importantly, when comparing the R-Squares of the life cycle model with that of the economy-wide and industry-specific model, we find that the explanatory power of life cycle model forecasts is significantly greater. These results also hold when investigating the last analyst forecast that is issued immediately prior to the earnings announcement. Although the R-squares are generally lower as analysts have the opportunity to incorporate additional information that comes out between the estimation of the

\footnotetext{
${ }^{6} \mathrm{We}$ find quantitatively comparable results when using median forecasts.
} 
mean-reverting model and the announcement of the actual earnings, we continue to find that the life cycle model explains more of the variation in analyst forecasts than the economy-wide and industry-specific models. $^{7}$

\section{[Table 7 about here]}

Although these results suggest that analysts (at least partially) recognize the importance of life cycle analyses, they do not speak to whether analysts fully incorporate the information from modelling mean reversion as a function of firm life cycle. Hence, in this section we investigate whether the improvements in forecast accuracy of the life cycle model relative to the forecasts from the economy-wide or industry-specific model can explain analyst forecast errors. If we find evidence that forecast improvements are associated with analyst forecast errors this suggests that analysts do not fully impound the information of life cycle analyses. We again use the first and last analyst consensus forecast and calculate analyst forecast errors as the absolute difference between the forecasted and the actual ROE as reported in I/B/E/S. The final sample consists of 15,841 firm-years with available accuracy data.

The results are reported in Table 7, Panel B. We find strong evidence that life cycle model improvements are associated with analyst forecast errors, suggesting that analysts underutilize life cycle information. Interestingly, these results also hold when investigating the last consensus forecast made prior to the earnings announcement. These forecasts may be issued up to 12 months after the development of the life cycle forecast and incorporate information from a variety of additional sources. Yet, even these forecasts can be improved by means of life cycle analyses.

\footnotetext{
${ }^{7}$ In untabulated analyses we further find that, consistent with the life cycle model not improving upon sales growth forecasts obtained from the industry model, there is no difference in the extent to which the life cycle model and industry-specific model are able to explain variation in analysts' forecasts of sales growth.
} 
Overall, the tests reported in this section provide evidence that analyst partially incorporate life cycle information into their forecasts. When investigating the relative association between analyst forecasts and forecasts obtained from economy-wide, industry-specific, and life cycle mean-reverting models, we find that the association is strongest between analyst forecasts and forecasts obtained from the life cycle model. However, analysts do not fully impound life cycle information as we find that analyst forecast errors are associated with life cycle model improvements in forecast accuracy.

\section{Alternative Life Cycle Classification}

Although the cash flow based life cycle measure we use is closely aligned with life cycle theory and for instance allows firms to move back and forth along the life cycle continuum, we nevertheless test the robustness of our results using an alternative life cycle measure. We use the life cycle measure from Anthony and Ramesh (1992) as adjusted by Hribar and Yehuda (2015). We classify firms into three life cycle stages (growth, maturity, and decline) based on past sales growth, capital expenditures, net capital transactions, and firm age. ${ }^{8}$ Although this measure does not allow firms to move along the life cycle continuum, the fact that it does not rely on cash flows addresses the concern that our results are driven by the sign of the cash flows, rather than firm life cycle. ${ }^{9}$ Importantly, we find quantitatively comparable results using this life cycle classification. Out-of-sample growth and profitability forecasts obtained from models estimated

\footnotetext{
${ }^{8}$ We follow Hribar and Yehuda (2015) and use net capital expenditures rather than cash dividends to reflect the fact that repurchases have become a popular way of distributing funds to shareholders. In addition, we add R\&D expenditures to a firm's capital expenditures to incorporate investments in intangible assets as these may have become more important in recent years.

${ }^{9}$ In untabulated tests, we further find that the greater accuracy of the life cycle models based on the classification of Dickinson (2011) is present for firms with both negative and positive lagged operating cash flows, providing further evidence that our results are not driven by a mechanical relation between the sign of the operating cash flows and future performance.
} 
by this alternative life cycle classification are more accurate than forecasts obtained from both economy-wide and industry-specific models.

\section{CONCLUSION}

In this paper, we investigate the relative performance of a life cycle model for predicting future growth and future profitability. Whereas mean-reversion in growth and profitability is a welldocumented phenomenon, we know less about what drives such mean-reversion. Estimating an economy-wide model would suffice if all firms in the economy are similar. However, there are considerable differences across firms when it comes to, for example, cost structures (Balakrishnan, Labro, and Soderstrom 2014), capital structures (Titman and Wessels 1988), and strategies (Knights and Morgan 1991), each of which may influence firm performance and its dynamics.

There is evidence that suggests that cross-sectional differences in many of these factors may be explained by a firm's industry membership, supporting the importance of industry in explaining a firm's fundamentals (Keeley and Roure 1990; Hawawini et al. 2003; Bou and Satorra 2007). Nevertheless, Fairfield et al. (2009) show that industry-level analyses do not improve the forecast accuracy of mean-reverting models of profitability and only improve the accuracy of long-term growth forecasts.

Building on literature that cites corporate life cycle as an important driver of firm decision making (Miller and Friesen 1983, 1984; Adizes 1979) and profitability and growth dynamics (Dickinson 2011; Anthony and Ramesh 1992), we investigate the out-of-sample forecast accuracy of forecasts obtained from a life cycle mean-reverting model. We find that life cycle model growth and profitability forecasts are more accurate than forecasts obtained from economy-wide and industry-specific models. Moreover, these results are not limited to year- 
ahead forecasts, but also hold when investigating two and three year-ahead forecasts and they are robust to using alternative life cycle classifications.

In subsequent tests, we investigate how these forecast improvements vary across life cycle stages and a variety of other firm characteristics. We find improvements in the accuracy of profitability (growth) forecasts for firms in the introduction, mature, and decline (introduction, mature, shakeout, and decline) stage, suggesting that the life cycle model performs well in most of the life cycle stages. When we investigate other characteristics that are associated with improvements in forecast accuracy from the life cycle model, we find that especially for profitability forecasts, there is evidence that improvements are positively associated with factors capturing firm uncertainty, such as idiosyncratic risk, greater variation in operating performance, R\&D and intangible asset intensity, and the reporting of special items. Finally, we find that analyst forecasts are consistent with the important role of firm life cycle, but that life cycle model forecast improvements are still associated with analyst forecast errors, suggesting that analysts only partially incorporate life cycle information.

Overall, we contribute to academic literature and FSA practice by documenting the usefulness of life cycle models for out-of-sample forecasting and by providing evidence on when the benefits of a life cycle model is largest. We also contribute to research on mean reversion in profitability by documenting a factor, namely life cycle, which affects the degree of mean reversion experienced by a firm. 


\section{REFERENCES}

Adizes, I. 1979. Organizational passages-diagnosing and treating lifecycle problems of organizations. Organizational dynamics 8 (1):3-25.

Anthony, J. H., and K. Ramesh. 1992. Association between accounting performance measures and stock prices: A test of the life cycle hypothesis. Journal of Accounting and Economics 15 (2):203-227.

Arikan, A. M., and R. M. Stulz. 2016. Corporate Acquisitions, Diversification, and the Firm's Life Cycle. The Journal of Finance 71 (1):139-194.

Balakrishnan, R., E. Labro, and N. S. Soderstrom. 2014. Cost structure and sticky costs. Journal of management accounting research 26 (2):91-116.

Bhojraj, S., C. Lee, and D. K. Oler. 2003. What's my line? A comparison of industry classification schemes for capital market research. Journal of Accounting Research 41 (5):745-774.

Bou, J. C., and A. Satorra. 2007. The persistence of abnormal returns at industry and firm levels: Evidence from Spain. Strategic management journal 28 (7):707-722.

Brown, N. C., and M. D. Kimbrough. 2011. Intangible investment and the importance of firmspecific factors in the determination of earnings. Review of accounting studies 16 (3):539-573.

Curtis, A. B., R. J. Lundholm, and S. E. McVay. 2014. Forecasting sales: A model and some evidence from the retail industry. Contemporary Accounting Research 31 (2):581-608.

DeAngelo, H., L. DeAngelo, and R. M. Stulz. 2006. Dividend policy and the earned/contributed capital mix: a test of the life-cycle theory. Journal of Financial Economics 81 (2):227254.

Dechow, P. M., and W. Ge. 2006. The persistence of earnings and cash flows and the role of special items: Implications for the accrual anomaly. Review of accounting studies 11 (23):253-296.

Dichev, I. D., J. R. Graham, C. R. Harvey, and S. Rajgopal. 2013. Earnings quality: Evidence from the field. Journal of Accounting and Economics 56 (2):1-33.

Dickinson, V. 2011. Cash flow patterns as a proxy for firm life cycle. The Accounting Review 86 (6):1969-1994.

Fairfield, P. M., S. Ramnath, and T. L. Yohn. 2009. Do Industry-Level Analyses Improve Forecasts of Financial Performance? Journal of Accounting Research 47 (1):147-178.

Fairfield, P. M., R. J. Sweeney, and T. L. Yohn. 1996. Accounting classification and the predictive content of earnings. The Accounting Review:337-355.

Fama, E. F., and J. D. MacBeth. 1973. Risk, return, and equilibrium: Empirical tests. Journal of political economy 81 (3):607-636.

Foster, G. 1981. Intra-industry information transfers associated with earnings releases. Journal of Accounting and Economics 3 (3):201-232.

Freeman, R. N., J. A. Ohlson, and S. H. Penman. 1982. Book rate-of-return and prediction of earnings changes: An empirical investigation. Journal of Accounting Research:639-653.

Gort, M., and S. Klepper. 1982. Time paths in the diffusion of product innovations. The economic journal 92 (367):630-653.

Grullon, G., R. Michaely, and B. Swaminathan. 2002. Are dividend changes a sign of firm maturity? The journal of Business 75 (3):387-424. 
Hanks, S. H., C. J. Watson, E. Jansen, and G. N. Chandler. 1993. Tightening the life-cycle construct: A taxonomic study of growth stage configurations in high-technology organizations. Entrepreneurship: Theory and Practice 18 (2):5-30.

Hawawini, G., V. Subramanian, and P. Verdin. 2003. Is performance driven by industry-or firmspecific factors? A new look at the evidence. Strategic management journal 24 (1):1-16.

Hayn, C. 1995. The information content of losses. Journal of Accounting and Economics 20 (2):125-153.

Healy, P., G. Serafeim, S. Srinivasan, and G. Yu. 2014. Market competition, earnings management, and persistence in accounting profitability around the world. Review of accounting studies 19 (4):1281-1308.

Hoberg, G., and G. Phillips. 2010. Product market synergies and competition in mergers and acquisitions: A text-based analysis. Review of Financial Studies 23 (10):3773-3811. . 2016. Text-based network industries and endogenous product differentiation. Journal of political economy 124 (5):1423-1465.

Hribar, P., and N. Yehuda. 2015. The Mispricing of Cash Flows and Accruals at Different LifeCycle Stages. Contemporary Accounting Research 32 (3):1053-1072.

Hui, K. W., K. K. Nelson, and P. E. Yeung. 2016. On the persistence and pricing of industrywide and firm-specific earnings, cash flows, and accruals. Journal of Accounting and Economics 61 (1):185-202.

Jawahar, I., and G. L. McLaughlin. 2001. Toward a descriptive stakeholder theory: An organizational life cycle approach. Academy of management review 26 (3):397-414.

Kadan, O., L. Madureira, R. Wang, and T. Zach. 2012. Analysts' industry expertise. Journal of Accounting and Economics 54 (2):95-120.

Kazanjian, R. K. 1988. Relation of dominant problems to stages of growth in technology-based new ventures. Academy of Management Journal 31 (2):257-279.

Keeley, R. H., and J. B. Roure. 1990. Management, strategy, and industry structure as influences on the success of new firms: A structural model. Management science 36 (10):12561267.

Kim, D., and Y. Qi. 2010. Accruals quality, stock returns, and macroeconomic conditions. The Accounting Review 85 (3):937-978.

Kimberly, J. R. 1979. Issues in the creation of organizations: Initiation, innovation, and institutionalization. Academy of Management Journal 22 (3):437-457.

Klein, A., and C. A. Marquardt. 2006. Fundamentals of accounting losses. The Accounting Review 81 (1):179-206.

Knights, D., and G. Morgan. 1991. Corporate strategy, organizations, and subjectivity: A critique. Organization studies 12 (2):251-273.

Koberg, C. S., N. Uhlenbruck, and Y. Sarason. 1996. Facilitators of organizational innovation: The role of life-cycle stage. Journal of business venturing 11 (2):133-149.

Lev, B. 1983. Some economic determinants of time-series properties of earnings. Journal of Accounting and Economics 5:31-48.

Lynall, M. D., B. R. Golden, and A. J. Hillman. 2003. Board composition from adolescence to maturity: A multitheoretic view. Academy of management review 28 (3):416-431.

Mashruwala, C., S. Rajgopal, and T. Shevlin. 2006. Why is the accrual anomaly not arbitraged away? The role of idiosyncratic risk and transaction costs. Journal of Accounting and Economics 42 (1):3-33. 
Miller, D., and P. H. Friesen. 1983. Successful and unsuccessful phases of the corporate life cycle. Organization studies 4 (4):339-356.

- 1984. A longitudinal study of the corporate life cycle. Management science 30 (10):1161-1183.

Milliman, J., M. A. Von Glinow, and M. Nathan. 1991. Organizational life cycles and strategic international human resource management in multinational companies: Implications for congruence theory. Academy of management review 16 (2):318-339.

Moores, K., and S. Yuen. 2001. Management accounting systems and organizational configuration: a life-cycle perspective. Accounting, organizations and society 26 (4):351389.

Nissim, D., and S. H. Penman. 2001. Ratio analysis and equity valuation: From research to practice. Review of accounting studies 6 (1):109-154.

Owen, S., and A. Yawson. 2010. Corporate life cycle and M\&A activity. Journal of Banking \& Finance 34 (2):427-440.

Owens, E. L., J. S. Wu, and J. Zimmerman. 2017. Idiosyncratic Shocks to Firm Underlying Economics and Abnormal Accruals. The Accounting Review 92 (2):183-219.

Porter, M. E. 1979. The structure within industries and companies' performance. The review of economics and statistics:214-227.

Quinn, R. E., and K. Cameron. 1983. Organizational life cycles and shifting criteria of effectiveness: Some preliminary evidence. Management science 29 (1):33-51.

Smith, K. G., T. R. Mitchell, and C. E. Summer. 1985. Top level management priorities in different stages of the organizational life cycle. Academy of Management Journal 28 (4):799-820.

Titman, S., and R. Wessels. 1988. The determinants of capital structure choice. The Journal of Finance 43 (1):1-19. 
TABLE 1

Descriptive Statistics

\begin{tabular}{lcrclc}
\hline \hline Panel A: In-sample Descriptive Statistics & & & & \\
& Mean & Std.Dev & P25 & Median & P75 \\
\hline GSALE & 0.0774 & 0.1833 & -0.0215 & 0.0653 & 0.1670 \\
GNOA $_{t}$ & 0.0666 & 0.2108 & -0.0509 & 0.0413 & 0.1622 \\
GCE $_{t}$ & 0.0600 & 0.1915 & -0.0320 & 0.0599 & 0.1541 \\
RNOA $_{t}$ & 0.1286 & 0.1659 & 0.0534 & 0.1195 & 0.2039 \\
ROE $_{t}$ & 0.0590 & 0.1678 & 0.0095 & 0.0896 & 0.1513
\end{tabular}

Panel B: In-sample Means per Life Cycle Stage

\begin{tabular}{lllllr} 
& $G S A L E_{t}$ & GNOA $_{t}$ & $G C E Q_{t}$ & RNOA $_{t}$ & ROE $_{t}$ \\
\hline Intro & 0.1114 & 0.0443 & 0.0254 & 0.0183 & -0.0547 \\
Growth & 0.1134 & 0.1016 & 0.0850 & 0.1254 & 0.0574 \\
Mature & 0.0529 & 0.0568 & 0.0598 & 0.1653 & 0.0938 \\
Shakeout & 0.0385 & 0.0233 & 0.0193 & 0.1005 & 0.0289 \\
Decline & 0.0631 & -0.0054 & -0.0252 & -0.0459 & -0.0890
\end{tabular}

Panel C: In-sample Standard Deviations per Life Cycle Stage

\begin{tabular}{lllllr} 
& $G S A L E_{t}$ & $G N O A_{t}$ & $G C E Q_{t}$ & $R N O A_{t}$ & $R O E_{t}$ \\
\hline Intro & 0.2285 & 0.2425 & 0.2378 & 0.1700 & 0.2187 \\
Growth & 0.1945 & 0.2158 & 0.1947 & 0.1506 & 0.1567 \\
Mature & 0.1539 & 0.1907 & 0.1732 & 0.1540 & 0.1453 \\
Shakeout & 0.1910 & 0.2293 & 0.1944 & 0.1817 & 0.1728 \\
Decline & 0.2295 & 0.2471 & 0.2223 & 0.2013 & 0.2122
\end{tabular}

Panel D: Correlations

\begin{tabular}{|c|c|c|c|c|c|c|c|c|c|c|}
\hline & $G S A L E_{t}$ & $G S A L E_{t-1}$ & $\mathrm{iNO}$ & $O A$ & $C$ & $C E$ & $R N O A$ & $O A_{t}$ & ${ }_{1} R O E_{t}$ & $R O E_{t-1}$ \\
\hline$G S A L E_{t}$ & 1.00 & 0.19 & 0.41 & 0.23 & 0.38 & 0.19 & 0.28 & 0.06 & 0.26 & 0.10 \\
\hline$G_{S A L E} E_{t-1}$ & 0.25 & 1.00 & 0.21 & 0.41 & 0.20 & 0.38 & 0.18 & 0.27 & 0.15 & 0.26 \\
\hline$G_{N O A_{t}}$ & 0.43 & 0.24 & 1.00 & 0.18 & 0.46 & 0.28 & 0.27 & 0.28 & 0.33 & 0.27 \\
\hline$G N O A_{t-1}$ & 0.25 & 0.43 & 0.23 & 1.00 & 0.14 & 0.46 & 0.10 & 0.27 & 0.11 & 0.33 \\
\hline$G C E Q_{t}$ & 0.42 & 0.24 & 0.47 & 0.17 & 1.00 & 0.27 & 0.44 & 0.25 & 0.61 & 0.26 \\
\hline$G C E Q_{t-1}$ & 0.23 & 0.42 & 0.33 & 0.47 & 0.34 & 1.00 & 0.28 & 0.43 & 0.27 & 0.59 \\
\hline$R N O A_{t}$ & 0.32 & 0.22 & 0.29 & 0.13 & 0.52 & 0.35 & 1.00 & 0.76 & 0.71 & 0.52 \\
\hline$R N O A_{t-1}$ & 0.10 & 0.31 & 0.31 & 0.29 & 0.32 & 0.51 & 0.77 & 1.00 & 0.51 & 0.71 \\
\hline$R O E_{t}$ & 0.31 & 0.21 & 0.34 & 0.15 & 0.61 & 0.34 & 0.83 & 0.62 & 1.00 & 0.55 \\
\hline$R O E_{t-1}$ & 0.12 & 0.31 & 0.32 & 0.34 & 0.33 & 0.60 & 0.63 & 0.83 & 0.66 & 1.00 \\
\hline
\end{tabular}

This table reports the in-sample descriptive statistics of the variables used in the main analyses. Panel A reports sample-wide descriptive statistics. Panel B (Panel C) reports means (standard deviations) per lagged life cycle stage. Panel D reports the correlation table. Spearman (Pearson) correlations are reported at the bottom (top). All correlations are significant at the one percent level. Life cycle classifications are based on the cash-flow proxy developed in Dickinson (2011). Variable Definitions can be found in Table 2 . 
TABLE 2

In Sample Mean-Reversion Estimation

\begin{tabular}{|c|c|c|c|c|c|c|}
\hline & \multicolumn{2}{|c|}{ Economy-wide Model } & \multicolumn{2}{|c|}{ Industry-Specific Model } & \multicolumn{2}{|c|}{ Life Cycle Model } \\
\hline & Mean Coef. & T-stat & Mean Coef. & T-stat & Mean Coef. & T-stat \\
\hline \multicolumn{7}{|l|}{ GSALE } \\
\hline Intercept & $0.0569 * * *$ & 47.63 & $0.0554 * * *$ & 52.38 & $0.0551 * * *$ & 39.81 \\
\hline$G S A L E_{t-1}$ & $0.1852 * * *$ & 19.58 & $0.1950 * * *$ & 39.58 & $0.1580 * * *$ & 21.46 \\
\hline \multicolumn{7}{|l|}{ GNOA } \\
\hline Intercept & $0.0456 * * *$ & 29.52 & $0.0473 * * *$ & 28.56 & $0.0181 * * *$ & 11.34 \\
\hline$G N O A_{t-1}$ & $0.1765 * * *$ & 40.62 & $0.1609 * * *$ & 27.63 & $0.1501 * * *$ & 37.18 \\
\hline \multicolumn{7}{|l|}{$G C E Q$} \\
\hline Intercept & $0.0421 * * *$ & 58.79 & $0.0437 * * *$ & 56.78 & $0.0236 * * *$ & 30.77 \\
\hline$G C E Q_{t-1}$ & $0.2696 * * *$ & 61.79 & $0.2499 * * *$ & 39.88 & $0.2228 * * *$ & 85.03 \\
\hline \multicolumn{7}{|l|}{ RNOA } \\
\hline Intercept & $0.0153 * * *$ & 28.43 & $0.0152 * * *$ & 31.01 & $0.0165 * * *$ & 42.17 \\
\hline$R N O A_{t-1}$ & $0.8299 * * *$ & 326.44 & $0.8284 * * *$ & 360.47 & $0.7472 * * *$ & 73.27 \\
\hline$N E G_{t-1}$ & $0.0022 * *$ & 2.18 & $0.0063^{* *}$ & 3.19 & $-0.0064 * * *$ & 7.19 \\
\hline$N E G^{*} R N O A_{t-1}$ & $-0.2905 * * *$ & 16.37 & $-0.3122 * * *$ & 12.76 & $-0.2616 * * *$ & 24.44 \\
\hline \multicolumn{7}{|l|}{$R O E$} \\
\hline Intercept & $-0.0038 * * *$ & 5.18 & $-0.0018 *$ & 2.07 & $-0.0095 * * *$ & 11.15 \\
\hline$R O E_{t-1}$ & $0.7989 * * *$ & 157.57 & $0.7766 * * *$ & 229.41 & $0.6422 * * *$ & 36.09 \\
\hline$N E G_{t-1}$ & $-0.0260 * * *$ & 15.66 & -0.0046 & 0.81 & $-0.0312 * * *$ & 36.35 \\
\hline$N E G^{*} R O E_{t-1}$ & $-0.5363 * * *$ & 71.45 & $-0.4083 * * *$ & 11.21 & $-0.3903 * * *$ & 34.21 \\
\hline \multicolumn{7}{|c|}{ 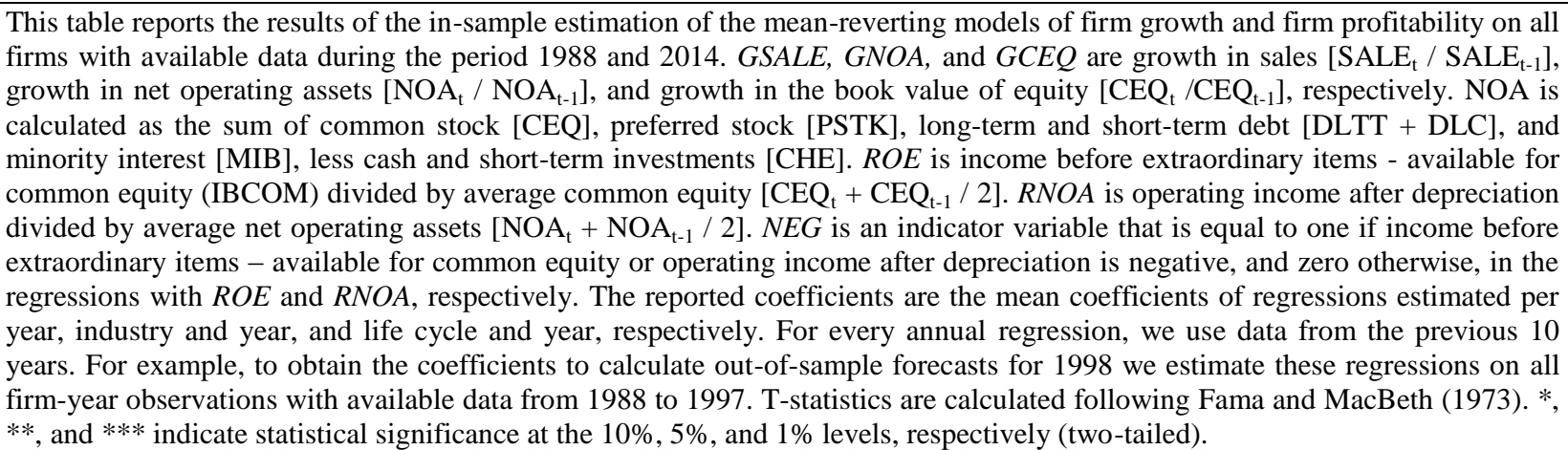 } \\
\hline
\end{tabular}


TABLE 3

Improvement in one-year ahead Forecast Accuracy

GSALE

Mean Impr.

Median Impr.

No. Years Mean

No. Years Median

GNOA

Mean Impr.

Median Impr.

No. Years Mean

No. Years Median

\section{GCEQ}

Mean Impr.

Median Impr.

No. Years Mean

No. Years Median
Life Cycle vs Economy-wide

Improvement

0.00047

0.00896

$12 / 1$

$10 / 2$

$\begin{array}{rr}0.00142 * * * & 0.00000 \\ -0.00011 & 0.76603 \\ 15 / 0 & \\ 6 / 3 & \end{array}$

$0.00084 * * *$

0.00003

0.00600

$12 / 0$

0.11871

$11 / 2$

RNOA

Mean Impr.

Median Impr.

No. Years Mean

No. Years Median

$\begin{array}{rr}0.00051 * * * & 0.00015 \\ 0.00181 * * * & 0.00042 \\ 7 / 0 & \end{array}$

$12 / 0$
Life Cycle vs Industry

Improvement

0.00051

0.30465

0.00011

0.22875

$8 / 3$

$5 / 2$

$\begin{array}{rr}0.00180 * * * & 0.00006 \\ 0.00076 * * & 0.01203 \\ 12 / 0 & \\ 10 / 0 & \end{array}$

$0.00156 * * *$
$0.00131 * * *$

0.00009

0.00475

$13 / 0$

$13 / 2$

\section{$R O E$}

Mean Impr.

$0.00179 * * *$

0.00000

$0.00292 * * *$

0.00000

Median Impr.

$0.00272 * * *$

0.00002

$0.00149 * * *$

0.00000

No. Years Mean

$17 / 0$

$0.00127 * * *$

0.00033

$12 / 0$

$15 / 0$

No. Years Median

$17 / 0$

$17 / 0$

This table reports the results of tests in which we investigate the extent to which profitability and growth forecasts obtained from life cycle mean-reverting models improve upon forecasts obtained from economy-wide and industry-specific models. We calculate paired forecast improvements by subtracting the life cycle model absolute forecast error from the absolute forecast error of the economy-wide and industry-specific model $\left(A F E_{E W} / A F E_{I N D}-A F E_{L C}\right)$. The out-of-sample tests are based on 40,466 firmyears with available data between 1998 and 2015. The reported mean (median) improvement is the grand mean (median) of 18 annual mean (median) improvement levels. Significance tests are based on whether the 18 annual mean (median) improvements are significant based on t-tests (Wilcoxon signed-rank tests). $* * *$, and $* * *$ indicate statistical significance at the $10 \%, 5 \%$, and $1 \%$ levels, respectively (two-tailed). No. Years shows the number of years (out of 18) in which improvement is significantly positive/negative (at the $10 \%$ significance level). 


\section{TABLE 4}

Improvement in one-year ahead Forecast Accuracy by Life Cycle

Panel A: Life Cycle vs Economy-wide

\section{Life Cycle Stages}

\begin{tabular}{ccccc} 
Introduction & Growth & Mature & Shakeout & Decline \\
\hline & & & & \\
$-0.00115^{* * *}$ & $0.00054^{* * *}$ & $0.00092^{* * *}$ & $0.00205^{* * *}$ & $0.00200^{* * *}$ \\
0.00006 & 0.00431 & 0.00000 & 0.00000 & 0.00293 \\
$-0.00220^{* * *}$ & 0.00906 & $0.00391 * * *$ & $0.01340^{* * *}$ & $0.00225 * * *$ \\
0.00000 & 0.29208 & 0.00000 & 0.00033 & 0.00062
\end{tabular}

GSALE

Mean Impr.

0.29208

GNOA

Mean Impr.

p-value

$\begin{array}{cc}0.01631^{* * *} & -0.00088^{* * *} \\ 0.00000 & 0.00000 \\ 0.05498^{* * *} & 0.00546^{* * *} \\ 0.00000 & 0.00000\end{array}$

$-0.00047^{* * * *}$

$0.00287 * * *$

$0.01549 * * *$

Median Impr.

p-value

$$
0.00000
$$

0.00000

$$
0.00000
$$

0.00000

$-0.00059^{* * *}$

$0.00335^{* * * *}$

0.00000

0.00000

$0.03065^{* * * *}$

GCEQ

Mean Impr

$$
0.00343 * * *
$$

$-0.00003$

$0.00018^{* * * *}$

$0.00220 * * *$

0.00000

p-value

0.00000

Median Impr.

0.76504

p-value

$0.01354 * * *$

$0.00112^{* *}$

0.00265

0.00001

0.04224

$-0.00023^{* *}$

0.00000

0.01613

$0.00595 * * *$

0.00000

$0.00984 * * *$

RNOA

\begin{tabular}{lccccc} 
Mean Impr. & $0.00202^{* * *}$ & $-0.00038^{* * *}$ & $0.00084^{* * *}$ & $-0.00065^{* * *}$ & $0.00354^{* * *}$ \\
p-value & 0.00005 & 0.00141 & 0.00000 & 0.00487 & 0.00018 \\
Median Impr. & $0.00207^{* * *}$ & $-0.00047^{* * *}$ & $0.00383^{* * *}$ & $-0.00012^{* *}$ & $0.00697 * * *$ \\
p-value & 0.00004 & 0.00347 & 0.00000 & 0.04671 & 0.00002 \\
ROE & & & & & \\
Mean Impr. & $0.00534 * * *$ & $-0.00113^{* * *}$ & $0.00317 * * *$ & $-0.00082^{* *}$ & $0.00841^{* * *}$ \\
p-value & 0.00000 & 0.00000 & 0.00000 & 0.02086 & 0.00001 \\
Median Impr. & $0.02147 * * *$ & $-0.00377^{* * *}$ & $0.00680^{* * *}$ & $-0.00087^{* * *}$ & $0.01975^{* * *}$ \\
p-value & 0.00000 & 0.00000 & 0.00000 & 0.00008 & 0.00000 \\
\hline
\end{tabular}


Panel B: Life Cycle vs Industry-specific

\begin{tabular}{|c|c|c|c|c|c|}
\hline & & & fe Cycle Stage & & \\
\hline & Introduction & Growth & Mature & Shakeout & Decline \\
\hline GSALE & & & & & \\
\hline Mean Impr. & -0.00007 & -0.00026 & $0.00073 * * *$ & $0.00170 * *$ & $0.00264 * *$ \\
\hline p-value & 0.92948 & 0.46792 & 0.00250 & 0.02517 & 0.04517 \\
\hline Median Impr. & -0.00116 & $-0.00037 *$ & $0.00043 * *$ & $0.00255^{* *}$ & 0.00078 \\
\hline $\mathrm{p}$-value & 0.21092 & 0.09181 & 0.01549 & 0.02214 & 0.10785 \\
\hline GNOA & & & & & \\
\hline Mean Impr. & $0.01651 * * *$ & 0.00004 & -0.00023 & $0.00267 * * *$ & $0.01516 * * *$ \\
\hline $\mathrm{p}$-value & 0.00000 & 0.88775 & 0.22192 & 0.00000 & 0.00000 \\
\hline Median Impr. & $0.04056 * * *$ & -0.00045 & -0.00015 & $0.00219 * * *$ & $0.03046 * * *$ \\
\hline p-value & 0.00000 & 0.54797 & 0.36125 & 0.00002 & 0.00000 \\
\hline$G C E Q$ & & & & & \\
\hline Mean Impr. & $0.00475 * * *$ & $0.00072 * *$ & $0.00086 * * *$ & $0.00216 * * *$ & $0.01125^{* * *}$ \\
\hline $\mathrm{p}$-value & 0.00000 & 0.01141 & 0.00005 & 0.00104 & 0.00000 \\
\hline Median Impr. & $0.00630 * * *$ & $0.00017 *$ & $0.00080 * * *$ & $0.00212 * * *$ & $0.01811 * * *$ \\
\hline p-value & 0.00000 & 0.05682 & 0.00000 & 0.00090 & 0.00000 \\
\hline RNOA & & & & & \\
\hline Mean Impr. & $0.00410 * * *$ & $0.00083 * * *$ & $0.00114 * * *$ & $0.00137 * *$ & $0.00719 * * *$ \\
\hline p-value & 0.00018 & 0.00009 & 0.00000 & 0.03705 & 0.00062 \\
\hline Median Impr. & $0.00275 * * *$ & $0.00042 * * *$ & $0.00078 * * *$ & $0.07420 * * *$ & $0.00505 * *$ \\
\hline $\mathrm{p}$-value & 0.00012 & 0.00012 & 0.00000 & 0.00505 & 0.00012 \\
\hline$R O E$ & & & & & \\
\hline Mean Impr. & $0.01075^{* * *}$ & 0.00001 & $0.00371 * * *$ & 0.00013 & $0.00876 * * *$ \\
\hline $\mathrm{p}$-value & 0.00198 & 0.95342 & 0.00000 & 0.82718 & 0.00003 \\
\hline Median Impr. & $0.00393 * * *$ & $-0.00150 * * *$ & $0.00304 * * *$ & -0.00024 & $0.00819 * * *$ \\
\hline $\mathrm{p}$-value & 0.00025 & 0.00000 & 0.00000 & 0.95865 & 0.00004 \\
\hline $\begin{array}{l}\text { This table reports th } \\
\text { life cycle mean-rev } \\
\text { on the firm's life cy } \\
\text { B reports the result } \\
\text { by subtracting the } \\
\text { specific model (AF } \\
1998 \text { and } 2015 \text {. Th } \\
\text { life cycle. Signific } \\
\text { (Wilcoxon signed-1 } \\
\text { tailed). }\end{array}$ & $\begin{array}{l}\text { ilts of tests in whi } \\
\text { models improve } u \\
\text { anel A reports the } \\
\text { mparing the life c } \\
\text { cle model absolut } \\
F E_{I N D}-A F E_{L C} \text { ). } \\
\text { tted mean (mediar } \\
\text { ests are based on } \\
\text { sts). *, **, and * }\end{array}$ & $\begin{array}{l}\text { e investigate the } \\
\text { forecasts obtaine } \\
\text { lts of tests compa } \\
\text { model to the indu } \\
\text { recast error from } \\
\text { out-of-sample tes } \\
\text { provement is the } \\
\text { ether the life cyc }\end{array}$ & $\begin{array}{l}\text { nt to which profi } \\
\text { om economy-wid } \\
\text { the life cycle m } \\
\text {-specific model. } \\
\text { absolute forecas } \\
\text { re based on } 40,4 \\
\text { an (median) impr } \\
\text { nean (median) it }\end{array}$ & $\begin{array}{l}\text { ity and growth f } \\
\text { d industry-specif } \\
\text { to the economy- } \\
\text { calculate paired } \\
\text { or of the econor } \\
\text { irm-years with a } \\
\text { ment across year } \\
\text { vement is signi }\end{array}$ & $\begin{array}{l}\text { casts obtained from } \\
\text { models, conditional } \\
\text { de model and Pane } \\
\text { ecast improvements } \\
\text { wide and industry- } \\
\text { lable data between } \\
\text { all firms within a } \\
\text { nt based on t-tests } \\
\text { respectively (two- }\end{array}$ \\
\hline
\end{tabular}


TABLE 5

Improvement in Long-Term Forecast Accuracy

Panel A: Two-year Ahead Forecast Accuracy

Life Cycle vs Economy-wide

Improvement

GSALE

Mean Impr.

Median Impr.

No. Years Mean

No. Years Median

\section{GNOA}

Mean Impr.

Median Impr.

No. Years Mean

No. Years Median

GCEQ

Mean Impr.

Median Impr.

No. Years Mean

No. Years Median

RNOA

Mean Impr.

Median Impr.

No. Years Mean

No. Years Median

ROE

Mean Impr.

Median Impr.

No. Years Mean

No. Years Median

$0.00054^{* * *} \quad 0.00002$

$0.00241 * * *$

$13 / 1$

$7 / 0$

0.00475
$0.00078^{* * * *}$
$0.00175^{* * * *}$
$11 / 0$
$12 / 0$

0.00001

0.00019

$\begin{array}{rr}0.00148 * * * & 0.00000 \\ 0.00472 * * * & 0.00004 \\ 14 / 0 & \\ 16 / 0 & \end{array}$

\section{Life Cycle vs Industry} Improvement p-value

0.65016

$-0.00026$

0.11871

$4 / 5$

$2 / 7$

$\begin{array}{cccc}0.00143^{* * *} & 0.00000 & 0.00170^{* * *} & 0.00007 \\ 0.00080^{* * *} & 0.00158 & 0.00100^{*} & 0.05994 \\ 15 / 0 & & 11 / 0 & \\ 15 / 1 & & 10 / 2 & \end{array}$

$\begin{array}{rrrr}0.00072^{* * *} & 0.00010 & 0.00113^{* *} & \\ 0.00157^{* * *} & 0.00004 & 0.00055 & \\ 11 / 0 & & 9 / 2 \\ 11 / 0 & & 8 / 3\end{array}$

0.03357

0.55087

$8 / 3$

$0.00236 * * *$

0.00000

$0.00109 * * *$

0.00053

$14 / 0$

$12 / 0$

$0.00299 * * *$

$0.00173 * * *$

0.00000

0.00002

$15 / 0$

$15 / 0$ 
Panel B: Three-year Ahead Forecast Accuracy

Life Cycle vs Economy-wide Life Cycle vs Industry

Improvement p-value Improvement p-value

GSALE

Mean Impr.

$0.00033^{* * *} \quad 0.00053$

0.00042

$-0.00037$

0.38493

Median Impr.

No. Years Mean

$0.00439 * * *$

$-0.00116^{* *}$

0.01593

No. Years Median

$6 / 0$

$8 / 1$

$3 / 3$

$2 / 8$

\section{GNOA}

Mean Impr.

$\begin{array}{ll}0.00113^{* * * *} & 0.00000 \\ 0.00075^{* * *} & 0.00001\end{array}$

$0.00130^{* * * *}$

0.00464

Median Impr.

No. Years Mean

$16 / 0$

0.00022

0.86504

No. Years Median

$14 / 0$

$9 / 0$

$7 / 1$

GCEQ

Mean Impr.

$0.00070 * * *$

0.00002

0.00085

0.10546

Median Impr.

$0.00185 * * *$

0.00001

$-0.00082$

0.24621

No. Years Mean

$10 / 0$

$7 / 2$

No. Years Median

$13 / 0$

$6 / 3$

RNOA

Mean Impr.

$0.00080 * * *$

0.00000

0.00807

0.15073

Median Impr.

$0.00092 * * *$

0.00281

$0.00034 *$

0.09874

No. Years Mean

$10 / 0$

$14 / 0$

No. Years Median

$13 / 0$

$9 / 2$

ROE

Mean Impr.

$0.00124 * * *$

0.00000

$0.00337 * * *$

0.00000

Median Impr.

$0.00125 * * *$

0.00011

$0.00173 * * *$

0.00042

No. Years Mean

$13 / 0$

$15 / 0$

No. Years Median

$11 / 0$

$13 / 0$

This table reports the results of tests in which we investigate the extent to which long-term profitability and growth forecasts obtained from life cycle mean-reverting models improve upon forecasts obtained from economy-wide and industry-specific models. Panel A reports the results of the tests investigating the relative forecast accuracy of two year-ahead forecasts and Panel $\mathrm{B}$ reports the results of the tests investigating the relative forecast accuracy of three year-ahead forecasts. Long-term profitability forecasts are defined as forecasts for two and three year-ahead profitability, whereas long-term growth forecasts are defined as forecasts for the annualized growth rate over a two- or three-year period. We calculate paired forecast improvements by subtracting the life cycle model absolute forecast error from the absolute forecast error of the economy-wide and industryspecific model $\left(A F E_{E W} / A F E_{I N D}-A F E_{L C}\right)$. The out-of-sample tests are based on 40,466 firm-years with available data between 1998 and 2015. The reported mean (median) improvement is the grand mean (median) of 18 annual mean (median) improvement levels. Significance tests are based on whether the 18 annual mean (median) improvements are significant based on t-tests (Wilcoxon signed-rank tests). $*, * *$, and $* * *$ indicate statistical significance at the $10 \%, 5 \%$, and $1 \%$ levels, respectively (twotailed). No. Years shows the number of years (out of 18) in which improvement is significantly positive/negative (at the $10 \%$ significance level). 
TABLE 6

Factors Associated with Forecast Improvements

Panel A: Improvements in Profitability Forecasts

\begin{tabular}{|c|c|c|c|c|}
\hline \multirow[t]{2}{*}{ Variable } & \multicolumn{2}{|c|}{$\boldsymbol{R N O A}$} & \multicolumn{2}{|c|}{$R O E$} \\
\hline & LC vs EW & LC vs IND & LC vs EW & LC vs IND \\
\hline \multirow[t]{2}{*}{ STD_IDIORET } & 0.002 & $0.042 * *$ & 0.024 & $0.098 * *$ \\
\hline & $(0.238)$ & $(2.195)$ & $(1.415)$ & $(2.244)$ \\
\hline \multirow[t]{2}{*}{ STDROA } & $0.017 * * *$ & $0.034 * *$ & $0.075 * * *$ & $0.057 * * *$ \\
\hline & $(2.589)$ & $(2.194)$ & $(5.696)$ & $(2.604)$ \\
\hline \multirow[t]{2}{*}{ ABNRET } & $-0.001 * * *$ & -0.000 & $-0.001 * * *$ & -0.001 \\
\hline & $(-3.635)$ & $(-1.128)$ & $(-3.837)$ & $(-1.500)$ \\
\hline \multirow[t]{2}{*}{$T V O L$} & 0.000 & -0.000 & $-0.000 *$ & -0.000 \\
\hline & $(0.029)$ & $(-0.169)$ & $(-1.795)$ & $(-1.019)$ \\
\hline \multirow[t]{2}{*}{ BETA } & $0.000 * *$ & $0.001 *$ & 0.000 & $0.001 * *$ \\
\hline & (1.999) & $(1.878)$ & $(0.899)$ & $(2.556)$ \\
\hline \multirow[t]{2}{*}{ INSTH } & $-0.002 * * *$ & 0.000 & $-0.003 * * *$ & $-0.004 * *$ \\
\hline & $(-4.119)$ & $(0.003)$ & $(-3.981)$ & $(-2.533)$ \\
\hline \multirow[t]{2}{*}{ ANALYST } & -0.000 & -0.000 & -0.000 & -0.000 \\
\hline & $(-0.951)$ & $(-0.385)$ & $(-0.649)$ & $(-0.994)$ \\
\hline \multirow[t]{2}{*}{$M T B$} & $0.000 * * *$ & 0.000 & $0.000 * * *$ & $0.001 * *$ \\
\hline & $(5.026)$ & (1.113) & $(4.003)$ & (1.969) \\
\hline \multirow[t]{2}{*}{ SIZE } & $0.000 *$ & -0.000 & 0.000 & -0.000 \\
\hline & (1.903) & $(-0.530)$ & $(0.872)$ & $(-0.094)$ \\
\hline \multirow[t]{2}{*}{ LEVERAGE } & -0.000 & $-0.003^{*}$ & $-0.002 *$ & -0.003 \\
\hline & $(-0.649)$ & $(-1.801)$ & $(-1.937)$ & $(-0.957)$ \\
\hline \multirow[t]{2}{*}{ RDINT } & 0.004 & 0.003 & $0.011 * * *$ & $0.012 *$ \\
\hline & $(1.516)$ & $(0.415)$ & $(2.580)$ & (1.864) \\
\hline \multirow[t]{2}{*}{ PPEINT } & 0.000 & 0.002 & $0.004 * * *$ & $0.003 * *$ \\
\hline & $(0.991)$ & (1.363) & $(3.936)$ & $(2.027)$ \\
\hline \multirow[t]{2}{*}{ INTANINT } & $0.001 * *$ & 0.001 & $0.007 * * *$ & $0.012 *$ \\
\hline & $(2.055)$ & (1.084) & $(6.340)$ & (1.944) \\
\hline \multirow[t]{2}{*}{ SPECIAL } & 0.000 & $0.001 * *$ & $0.001 * * *$ & $0.002 * * *$ \\
\hline & $(0.968)$ & $(2.195)$ & $(3.479)$ & $(2.645)$ \\
\hline \multirow[t]{2}{*}{ Constant } & $-0.001 * *$ & -0.002 & $-0.003 * * *$ & $-0.004 * *$ \\
\hline & $(-2.217)$ & $(-1.291)$ & $(-2.638)$ & $(-2.276)$ \\
\hline Observations & 31,737 & 31,737 & 31,737 & 31,737 \\
\hline R-squared & 0.005 & 0.002 & 0.010 & 0.003 \\
\hline
\end{tabular}


Panel B: Improvements in Growth Forecasts

\begin{tabular}{|c|c|c|c|c|c|c|}
\hline \multirow[t]{2}{*}{ Variable } & \multicolumn{2}{|c|}{ GSALE } & \multicolumn{2}{|c|}{ GNOA } & \multicolumn{2}{|c|}{ GCEQ } \\
\hline & LC vs EW & LC vs IND & LC vs EW & LC vs IND & LC vs EW & LC vs IND \\
\hline \multirow[t]{2}{*}{ STD_IDIORET } & -0.015 & -0.022 & $0.097 * * *$ & $0.149 * * *$ & 0.018 & $0.044 * *$ \\
\hline & $(-1.522)$ & $(-1.008)$ & $(5.956)$ & $(7.014)$ & $(1.516)$ & (2.039) \\
\hline \multirow[t]{2}{*}{ STDROA } & -0.000 & -0.012 & $0.041 * * *$ & $0.047 * * *$ & $0.025 * * *$ & 0.003 \\
\hline & $(-0.027)$ & $(-0.749)$ & $(3.781)$ & $(3.118)$ & $(3.100)$ & $(0.224)$ \\
\hline \multirow[t]{2}{*}{$A B N R E T$} & $0.001 * * *$ & $-0.001 * *$ & $-0.002 * * *$ & $-0.002 * * *$ & $-0.001 * * *$ & $-0.002 * * *$ \\
\hline & $(3.701)$ & $(-2.133)$ & $(-5.599)$ & $(-6.101)$ & $(-3.855)$ & $(-4.625)$ \\
\hline \multirow[t]{2}{*}{ TVOL } & 0.000 & $-0.000 *$ & 0.000 & 0.000 & 0.000 & 0.000 \\
\hline & $(0.450)$ & $(-1.721)$ & $(0.072)$ & $(0.743)$ & $(0.688)$ & $(0.872)$ \\
\hline \multirow[t]{2}{*}{ BETA } & $-0.001 * * *$ & $0.002 * * *$ & -0.000 & 0.000 & 0.000 & $0.002 * * *$ \\
\hline & $(-2.657)$ & $(3.437)$ & $(-0.617)$ & $(0.984)$ & $(0.269)$ & $(3.712)$ \\
\hline \multirow[t]{2}{*}{ INSTH } & 0.001 & $-0.004 * * *$ & 0.000 & -0.000 & $-0.001 *$ & $-0.002 * * *$ \\
\hline & (1.413) & $(-3.333)$ & $(0.106)$ & $(-0.432)$ & $(-1.807)$ & $(-2.626)$ \\
\hline \multirow[t]{2}{*}{ ANALYST } & -0.000 & -0.000 & $0.000 *$ & -0.000 & -0.000 & -0.000 \\
\hline & $(-0.560)$ & $(-1.234)$ & (1.801) & $(-0.541)$ & $(-0.217)$ & $(-0.754)$ \\
\hline \multirow[t]{2}{*}{$M T B$} & 0.000 & $-0.001 * * *$ & $0.000 *$ & -0.000 & $0.000 * *$ & $-0.000 * * *$ \\
\hline & (1.109) & $(-5.366)$ & (1.930) & $(-0.345)$ & $(2.241)$ & $(-2.641)$ \\
\hline \multirow[t]{2}{*}{$S I Z E$} & 0.000 & $0.001 * * *$ & $-0.000 * * *$ & -0.000 & -0.000 & 0.000 \\
\hline & $(0.402)$ & $(3.266)$ & $(-4.028)$ & $(-0.269)$ & $(-0.798)$ & $(0.615)$ \\
\hline \multirow[t]{2}{*}{ LEVERAGE } & -0.000 & $0.003^{*}$ & $-0.002 *$ & -0.001 & $-0.004 * * *$ & $-0.005 * * *$ \\
\hline & $(-0.527)$ & (1.811) & $(-1.889)$ & $(-0.654)$ & $(-4.585)$ & $(-3.580)$ \\
\hline \multirow[t]{2}{*}{$R D I N T$} & $-0.005 * *$ & $0.010 * *$ & $0.011 * *$ & -0.006 & 0.002 & $0.010 * *$ \\
\hline & $(-2.184)$ & $(1.971)$ & $(2.565)$ & $(-0.983)$ & $(0.670)$ & $(2.101)$ \\
\hline \multirow[t]{2}{*}{ PPEINT } & 0.001 & 0.001 & -0.001 & -0.001 & 0.000 & $0.003 * *$ \\
\hline & $(1.321)$ & $(0.719)$ & $(-0.736)$ & $(-0.485)$ & $(0.180)$ & $(2.049)$ \\
\hline \multirow[t]{2}{*}{ INTANINT } & $0.003 * * *$ & $0.003 * *$ & -0.000 & $-0.003 *$ & $0.002 * * *$ & $0.002 *$ \\
\hline & $(4.011)$ & $(2.060)$ & $(-0.164)$ & $(-1.943)$ & $(2.762)$ & $(1.756)$ \\
\hline \multirow[t]{2}{*}{ SPECIAL } & -0.000 & -0.001 & 0.000 & 0.001 & 0.000 & 0.000 \\
\hline & $(-0.800)$ & $(-1.374)$ & $(1.274)$ & $(1.324)$ & $(1.278)$ & $(0.883)$ \\
\hline \multirow[t]{2}{*}{ Constant } & 0.001 & -0.000 & 0.000 & $-0.002 *$ & 0.000 & -0.000 \\
\hline & $(1.181)$ & $(-0.284)$ & $(0.168)$ & $(-1.663)$ & $(0.571)$ & $(-0.232)$ \\
\hline Observations & 31,737 & 31,737 & 31,737 & 31,737 & 31,737 & 31,737 \\
\hline R-squared & 0.003 & 0.003 & 0.013 & 0.009 & 0.005 & 0.004 \\
\hline
\end{tabular}

This table reports the results of tests in which we investigate factors that are associated with the extent to which profitability and growth forecasts obtained from life cycle mean-reverting models improve upon forecasts obtained from economy-wide and industry-specific models. Panel A reports the results of the tests investigating the relative accuracy of profitability forecasts and Panel B reports the results of the tests investigating the relative accuracy of growth forecasts. We calculate paired forecast improvements by subtracting the life cycle model absolute forecast error from the absolute forecast error of the economy-wide and industry-specific model $\left(A F E_{E W} / A F E_{I N D}-A F E_{L C}\right)$. The tests are based on 31,737 firm-years with available data between 1998 and 2015. STD_IDIORET is the standard deviation of daily market model residual returns, using CRSP's value weighted return as the market return and is estimated over the one-year period from the fourth month after the start of the fiscal year to the third month after the fiscal year-end. STDROA is the standard deviation of quarterly return on assets $\left(\mathrm{IBQ}_{\mathrm{t}} / \mathrm{ATQ}_{\mathrm{t}-1}\right)$, measured over 20 quarters and requiring a minimum of 8 quarters. ABNRET is the firm's 12-month abnormal return, where we subtract CRSP's value weighted market return from the firm's return to calculate abnormal returns. TVOL is the 12-month sum of monthly trading volume scaled by shares outstanding (VOL / SHROUT). BETA is the coefficient on market returns of a regression of firm returns on CRSP's value-weighted returns. ABNRET, TVOL, and BETA are all calculated over the same one-year window that we use to 
calculate STD_IDIORET. ANALYST is the number of analysts issuing annual earnings forecasts in I/B/E/S. INSTH is the percentage of shares owned by institutions based on the Thomson Reuters' Institutional Holdings (13f) database. MTB is the market-to-book ratio (PRCC_F * CSHO / CEQ). SIZE is the natural logarithm of total assets. LEVERAGE is total debt over total assets (DLC + DLTT / AT). RDINT is R\&D expense scaled by lagged total assets $\left(\mathrm{XRD}_{\mathrm{t}} / \mathrm{AT}_{\mathrm{t}-1}\right)$. We set missing R\&D to zero as long as SG\&A (XSGA) or Advertising expense (XAD) are not missing. PPEINT is measured as net property plant and equipment over total assets (PPENT / AT). INTANINT is intangible assets over total assets (INTAN / AT). SPECIAL, is an indicator variable for whether the firm reported special items (abs[SPI] > 0). *, **, and *** indicate statistical significance at the $10 \%, 5 \%$, and $1 \%$ levels, respectively (two-tailed). Reported T-statistics are based on standard errors clustered at firm level. 
TABLE 7

Analyst ROE Forecasts and Life Cycle Model Predictions and Improvements

Panel A: Relation between Analyst ROE Forecasts and Model ROE Predictions

\begin{tabular}{|c|c|c|c|}
\hline \multirow[b]{2}{*}{ Variable } & EW-Model & IND-Model & LC-Model \\
\hline & \multicolumn{3}{|c|}{ Depvar: First Analyst Forecast } \\
\hline Intercept & $0.0711 * * *$ & $0.0713 * * *$ & $0.0689 * * *$ \\
\hline Pred_ROE & $0.7595^{* * * *}$ & $0.7520 * * *$ & $0.7675^{* * *}$ \\
\hline R-Squared & $52.04 \%$ & $51.42 \%$ & $53.25 \%$ \\
\hline \multirow[t]{2}{*}{$\begin{array}{l}\text { Diff. in } R^{2} \text { Vuong Test } \\
\text { EW/LC \& IND/LC }\end{array}$} & $6.47 * * *$ & $5.74 * * *$ & \\
\hline & EW-Model & IND-Model & LC-Model \\
\hline Variable & \multicolumn{3}{|c|}{ Depvar: Last Analyst Forecast } \\
\hline Intercept & $0.0557 * * *$ & $0.0562 * * *$ & $0.0530 * * *$ \\
\hline Pred_ROE & $0.8227 * * *$ & $0.8109 * * *$ & $0.8353 * * *$ \\
\hline R-Squared & $44.25 \%$ & $43.32 \%$ & $45.72 \%$ \\
\hline $\begin{array}{l}\text { Diff. in } \mathrm{R}^{2} \text { Vuong Test } \\
\text { EW/LC \& IND/LC }\end{array}$ & $8.20^{* * *}$ & $7.38 * * *$ & \\
\hline
\end{tabular}

Panel B: Relation between Analyst ROE Forecast Errors and Life Cycle Model Improvements

\begin{tabular}{|c|c|c|}
\hline & $\begin{array}{c}\text { Life Cycle vs } \\
\text { Economy-wide }\end{array}$ & $\begin{array}{c}\text { Life Cycle vs } \\
\text { Industry-specific }\end{array}$ \\
\hline Variable & \multicolumn{2}{|c|}{ Depvar: First Absolute Analyst Forecast Error $(A B S F E)$} \\
\hline Intercept & $0.0586 * * *$ & $0.0585 * * *$ \\
\hline Improvement & $0.1850 *$ & $0.1670 * * *$ \\
\hline \multirow[t]{2}{*}{ R-Squared } & $0.07 \%$ & $0.15 \%$ \\
\hline & $\begin{array}{l}\text { Life Cycle vs } \\
\text { Economy-wide }\end{array}$ & $\begin{array}{c}\text { Life Cycle vs } \\
\text { Industry-specific }\end{array}$ \\
\hline Variable & \multicolumn{2}{|c|}{ Depvar: Last Absolute Analyst Forecast Error (ABSFE) } \\
\hline Intercept & $0.0376^{* * *}$ & $0.0376 * * *$ \\
\hline Improvement & $0.1509 * *$ & $0.1036 * *$ \\
\hline R-Squared & $0.09 \%$ & $0.11 \%$ \\
\hline \multicolumn{3}{|c|}{$\begin{array}{l}\text { This table reports the results of tests in which we investigate the relation between life cycle model ROE forecasts } \\
\text { and analyst ROE forecasts (Panel A) and life cycle model improvements and analyst ROE forecast errors (Panel B). } \\
\text { In both tests we use both the first and last consensus (mean) ROE forecast in IBES. The first forecast is defined as } \\
\text { the first forecast in IBES issued after the announcement of year } t-1 \text { earnings. The last forecast is the last forecast } \\
\text { made prior to the announcement of year } t \text { earnings. Forecast errors (ABSFE) are calculated as the absolute difference } \\
\text { between consensu ROE forecasts and the actual ROE as reported in IBES. The sample in Panel A (Panel B) } \\
\text { consists out of } 18,661(15,841) \text { firm-year observations with available data on analyst ROE forecasts (forecast }\end{array}$} \\
\hline
\end{tabular}


errors). Panel A reports Voung test Z-statistics for the difference in R-Squares between models of analyst ROE forecasts on forecasts from the economy-wide, industry-specific, and life-cycle model, respectively. *, **, and *** indicate statistical significance at the $10 \%, 5 \%$, and $1 \%$ levels, respectively (two-tailed). Reported significance levels are based on standard errors clustered at firm level. 